This is a self-archived - parallel published version of this article in the publication archive of the University of Vaasa. It might differ from the original.

\title{
Effectual Networks as Complex Adaptive Systems : Exploring Dynamic and Structural Factors of Emergence
}

Author(s): Galkina, Tamara; Atkova, Irina

Title: $\quad$ Effectual Networks as Complex Adaptive Systems : Exploring Dynamic and Structural Factors of Emergence

Year: $\quad 2019$

Version: Accepted manuscript

Copyright SAGE Publishing

Please cite the original version:

Galkina, T., \& Atkova, I., (2019). Effectual Networks as Complex Adaptive Systems : Exploring Dynamic and Structural Factors of Emergence. Entrepreneurship theory and practice, First Online October 4. https://doi.org/10.1177/ 1042258719879670 
EFFECTUAL NETWORKS AS COMPLEX ADAPTIVE SYSTEMS: EXPLORING DYNAMIC AND STRUCTURAL FACTORS OF EMERGENCE

Abstract:

The notion of effectual networks is one of the central concepts in the effectuation research. However, there has been little conceptual and empirical work on how they emerge and what structures they have. This article incorporates the concept of complex adaptive systems from complexity theory to understand both their dynamic and structural elements. We examine the effectual networks and networking of ten startups from Finland and offer a process-system model of effectual networks. We derive propositions that connect dynamic and structural entrepreneur-related factors of their emergence and outline directions for future research at the intersection of effectuation and complexity theory.

Key words: complexity theory, complex adaptive systems, effectuation, effectual networks

\section{INTRODUCTION}

Effectuation research has been developing for about two decades and is recognized as an important paradigmatic shift in understanding entrepreneurial decision-making and behavior (Alsos et al., 2019). Despite its considerable progress as a theory, many of its concepts require theoretical and empirical improvements (Arend et al., 2015; Read et al., 2016; McKelvie et al., 2019). For instance, while effectual networks are the key building blocks of the effectuation process aiding decision making under highly uncertain conditions (see e.g., Sarasvathy \& Dew, 2003; 2005), our knowledge about their formation and constitution is still incomplete (Kerr \& Coviello, 2019). As an illustration, Chandler et al. (2011) argue that the deployment of network alliances and precommitments is equally implemented in both causation and effectuation. Therefore, scholars still have insufficient understanding on how entrepreneurial relations are formed and structured under uncertainty (Partanen et al., 2011; Sullivan \& Ford, 2013; Burns et al., 2016).

Given the iterative, process-based and network-dependent nature of effectuation (Jiang \& Ruling, 2019), it is not surprising that effectuation scholars also suggest "to rethink their affiliation with equilibrium... and embrace the many disequilibrating aspects of entrepreneurship" and use "the dissipative structures 
strand of complexity theory" (Gupta et al., 2016: 543). Complexity theory (Lewin, 1992; Thrift, 1999; Walby, 2007) has started to attract entrepreneurship scholars because of its emphasis on order creation in open, uncertain, non-linear and dynamic systems, which entrepreneurial ventures are (Maguire et al., 2006; Lichtenstein et al., 2007; McKelvey, 2004). The notion of a complex adaptive system (CASs) is one of the key concepts in complexity theory defined as "a group of semi-autonomous agents who interact in interdependent ways to produce system-wide patterns, such that those patterns then influence behavior of the agents" (Dooley, 1996: 3). In relation to human systems, these agents are interdependent individuals or groups whose constant interactions generate patterns of behavior that grow into sustained system-wide characteristics (Dooley \& Van de Ven, 1999). Complexity theory in general and CASs in particular do not focus on static states but seek to explain how different systems emerge, adapt and evolve and how these processes unfold under complex and uncertain conditions (Walby, 2007). Therefore, they can serve as novel and valid instruments for theorizing about effectual networks and comprehending the dynamics of entrepreneurial networks under uncertainty. Therefore, our central research aim is to explore and conceptualize effectual networks as complex adaptive systems and to identify entrepreneur-related dynamic and structural factors of their emergence.

In this study, we demonstrate a congruence between CASs and effectual networks, and suggest this consistency makes several important contributions. First, by combining conceptual lenses (Okhuysen, \& Bonardi, 2011), we respond to the aforementioned calls to build a connection between complexity theory and entrepreneurial effectuation. This is especially important for effectuation to gain more maturity and diffuse into other research streams (Arend et al., 2015; Matalamäki, 2017; Alsos et al., 2019). CAS perspective helps to advance the concept of effectual networks because it offers a process-system approach to explore entrepreneur-related factors on how effectual networks emerge; this, in turn, adds more understanding of entrepreneurial networking under conditions of uncertainty (Engel et al., 2017). Our synthesizing approach is novel and contributes to the broader process-oriented research on entrepreneurial 
networks (Jack et al., 2010; Jack, 2010). The previous studies on entrepreneurial networks focused on either their dynamics (Larson \& Starr, 1993; Hite, \& Hesterly, 2001; Coviello, 2006) or structural characteristics (Staber, 1993; Diánez-González \& Camelo-Ordaz, 2017), without producing an integrative picture. Our CAS perspective, in turn, allows for coupling both the structural and dynamic factors of effectual network emergence and, therefore, follows an integral approach focusing both on what and how of effectual networks (Kerr \& Coviello, 2019). It also connects their entrepreneur-level agentic features with systemlevel reactive features, which allows micro-levels of analysis (a node level of an entrepreneur and his/her means) to be related with higher levels of analysis (a structural level of an effectual network as a system). Second, combining two theories connects the notions of complexity and uncertainty. While complexity may be one of the main sources of uncertainty (Simon, 1969; Kauffman, 1993), the link between these concepts has not been established in the effectuation and broader entrepreneurship research. Yet, it offers new insights into entrepreneurial network emergence under uncertainty. Below, we introduce complexity theory and provide an overview of CASs and their implications for understanding effectual networks.

\section{THEORETICAL BACKGROUND}

\subsection{Complex adaptive systems (CASs): basic tenets and stepping stones ${ }^{1}$}

Although its name might suggest otherwise, complexity theory is not a unified body of theory but a broad array of ideas, concepts, techniques and theories concerned with complex systems (Lewin, 1992; Hogue \& Lord, 2007; Walby, 2007). Lissack (1999: 112) argues it is "a collection of ideas that have in common the notion that within dynamic patterns there may be underlying simplicity that can, in part, be discovered through large quantities of computer power... and through analytic, logical, and conceptual

\footnotetext{
${ }^{1}$ We chose the concept of CASs instead of complex adaptive networks (CANs) for several reasons. First, the concepts of CAS and CAN are closely related. Yet, according to Choi et al. (2001), the concept of CAS is a wider one. The authors define a CAS as "an interconnected network of multiple entities (or agents) that exhibit adaptive action in response to changes in both the environment and the system of entities itself". Second, in the extant literature, the concept of CAS appears to be much stronger and more established, providing a more solid link to complexity theory. Hence, selecting the CAN concept would offer a narrower view and a weaker link between CASs and effectual networks.
} 
developments...". The underlying assumption of this theory is the notion of complexity, which refers to inability to evaluate and predict the outcomes of actions because too many parameters interact. Hence, even though the variables can be known, the effects of their interaction cannot be assessed, which, in turn, can be a source of uncertainty (Simon, 1969: 195; Kauffman, 1993: 42).

Recently, complexity theory has been widely used in organizational science to problematize a linear and mechanistic view of organizations (Plowman, 2007). From the complexity theory perspective, organizations are best understood as CASs comprised of dynamic networks of relationships (Hogue \& Lord, 2007), where complexity arises from the adaptive behavior of the agents (Morel \& Ramanujam, 1999). This perspective enables to understand complex organizational dynamics and organizational change. CASs share several common principles.

1) Sensitivity to initial conditions. This principle suggests that a small event or a pre-condition can have a variety of implications for the system. It can trigger fundamental changes, have no influence or can produce changes in CASs disproportional to the event (Schneider \& Sommers, 2006). A large disproportionate change is frequently exemplified by the butterfly effect, i.e., the idea that a butterfly fluttering in Rio de Janeiro can change the weather in Chicago (Kauffman, 1993). Thus, initial conditions shape a non-linear system in a unique and unpredictable way. Hence, CASs are predictable in patterns but not predictable in paths.

2) Non-linearity. This principle is tightly linked to the previous one. In CASs, non-linearity is understood as a lack of proportionality between input and output, implying there is no direct relationship between them (Anderson, 1999). At the same time, non-linearity is perceived as a result of multiple interactions between the elements of a system that are connected by feedback mechanisms (Morel \& Ramanujam, 1999). Kitson et al. (2018: 236) explain that generally non-linearity refers to the "nonpredictable nature of the relationships, behaviors and interactions that are created and occur within CAS. It also refers to the fact that small changes in inputs, physical interactions or stimuli can cause large effects 
or very significant changes in outputs".

3) Adaptability. Evolving from the interdependency of individual elements, the emergent characteristic of self-organization allows CASs to adapt to changes in external or internal conditions. The idea of adaptability is associated with the process of learning. The adaptable system is approached as being able to learn from its past experience to better respond to the endogenous and exogenous challenges. Thus, learning is critical for order to emerge, and can be guided by order-generating rules (Hogue \& Lord, 2007).

4) Non-predictable behavior. CASs are intrinsically non-predictable in character producing surprising, emergent behavior patterns. It implies that it is impossible to predict the system state at any particular point in time. However, CASs have some degree of stability and are subject to unpredictable developments only periodically (Harvey \& Reed, 1994). Patterns of system behavior emerge in an irregular but similar fashion through a process of self-organization, which is regulated by order-generating rules (Burnes, 2005). Although the complexity theory approach cannot necessarily predict how given systems will evolve, it allows understanding them through formal models and grasping behavioral patterns (Anderson et al., 1999).

5) Connectivity. The connectivity principle suggests that elements of a system are partially connected to each other by positive and negative feedback loops. These loops allow a system to adjust to the environment by adapting to both internal and external influences (Anderson, 1999; Coleman, 1999). "Patterns which enhance a system's ability to adapt successfully to its environment are stabilized and repeated; those that do not are rejected in favor of radically new ones, almost as if a cosmic game of trialand-error were being played. Complexity is, therefore, in part, the study of pervasive innovation in the universe." (McElroy, 2000: 196). In other words, systems are organized by means of feedback loops that generate stable structures (Drazin \& Sandelands, 1992).

6) Emergent self-organization. This principle is closely linked to the principle of adaptability. While complex systems have many characteristics, Chiles et al. (2004: 502) describe the concept of emergent selforganization as "anchor point phenomenon". CASs comprise a large number of elements or agents that 
interact with one another, determining the so-called "emergent properties" (Morel \& Ramanujam, 1999: 279), which evolve as a result of the collective behavior of the system components. In self-organizing systems, order emerges from the actions of interdependent agents who exchange information (Plowman, 2007). Interactions between entities at a lower level in the system produce system-level order meaning that a system can be understood through the sub-component relationships (Anderson, 1999). This order revolves around a so-called attractor, which is "a limited area in a system's state space that it never departs" (Anderson, 1999: 217). An attractor structures non-random behavior into a system, as behavioral patterns emerge within the basin of attraction (Schneider \& Sommers, 2006). This system tends to be highly resistant to change from one attractor towards another (Svyantek \& DeShon, 1993). Therefore, patterns reproduced at the micro-level become observable and define the system at the macro-level (Thietart, \& Forgues, 1995).

7) Co-evolution. The principle of co-evolution follows from the connectivity of systems components. Being interdependent and connected by feedback loops, the elements of CAS co-evolve by mutually influencing each other (Anderson, 1999). Also, not all systems have an equal capacity to evolve (Kauffman, 1993). Highly chaotic or ordered systems tend to fail due to the absence or excessive presence of stable

elements. Yet, "poised” systems “....may have special relevance to evolution because they seem to have the optimal capacity for evolving" through the accumulation of useful variations (Kauffman, 1991: 82).

In sum, the complexity theory research focuses on CASs, i.e. networks of interacting agents, providing an explanation of how new things emerge. These elements of agents interact in ways that produce nonlinear, emergent dynamics and generate creativity, learning, and adaptability.

\subsection{Effectual networks as Complex Adaptive Systems}

\subsubsection{Origins and nature of relations}

The notion of effectual networks stems from the theory of effectuation developed by Sarasvathy (2001) within entrepreneurship research. She indicates that "causation processes take a particular effect as given and focus on selecting between means to create that effect. Effectuation processes take a set of means as 
given and focus on selecting between possible effects that can be created with that set of means" (Sarasvathy 2001: 245). Causal logic is more applicable when the future is predictable, the goal can be specified, and preferences about environments in which to operate can be expressed. Hence, the underlying assumptions of effectual logic are conditions of Knightian uncertainty (future is not only unknown but also unknowable), unspecified goals, and environmental isotropy (Sarasvathy, 2001; Welter, \& Kim, 2018)

The phrase 'effectual networks' was coined in the study by Sarasvathy \& Dew (2003) where they emphasized non-goal-driven, exploratory and non-predictive nature of networks formed under effectuation. Further studies also highlight their differences from more general entrepreneurial networks because they are subject to different assumptions (Sarasvathy \& Dew, 2005; Engel et al., 2017; Kerr \& Coviello, 2019). According to Slotte-Kock and Coviello (2010), the entrepreneurial network domain is largely informed by the business network approach and the social network approach. These approaches largely assume that network relations can be coordinated through developing a favorable network position according to some resource needs ${ }^{2}$. Taking this stand, Slotte-Kock and Coviello (2010: 46) and Hansen (1995: 17), argue that entrepreneurial network relations can and should be managed. Also, Larson (1991: 174) states that "an entrepreneurial firm's ability to identify, cultivate, and manage... network partnerships is critical to survival and success". In this regard, the study by Jack et al. (2010) is highly revealing as it shows how an entrepreneurial network can be instrumentally created through a top-down mechanism and formalized purposeful exchanges. In the entrepreneurial network research tradition, relations are grounded in repeated stable interactions that have a history (Jack et al., 2008; Jack et al. 2010). Hence, trust is recognized as an important mechanism for discouraging opportunistic behavior and decreasing risks (Larson, 1991; Hoang, \& Antoncic, 2003; Neergaard, \& Ulhøi, 2006). In addition, the entrepreneurial network research is to a great extent grounded in the resource-based view examining what instrumental resources can be obtained

\footnotetext{
${ }^{2}$ See e.g. Jarillo (1988); Koon \& Low (1997); Hunterhuber \& Hirsch (1998); Ritter, Wilkinson \& Johnston (2004); Håkansson \& Ford (2002); Håkansson \& Snehota (1995); Håkansson, \& Ford (2002) for business networks and e.g. Burt (1995; 2004); Granovetter (1973; 1985); Uzzi (1997); Podolny (2001); Kilduff \& Tsai (2003) for social networks.
} 
by entrepreneurs from various relations to satisfy known venture needs (see e.g., Greve, \& Salaff, 2003; Lechner, \& Dowling, 2003). In general, entrepreneurial networks are viewed as systems that "do not form by chance but can be studied as patterned, predictable exchange structures" (Larson, 1991: 173).

Effectual networks are built upon dissimilar assumptions. Due to uncertainty, they are open to a diversity of outcomes and cannot be coordinated by a focal entrepreneur because the motives and incentives of other actors are unknown (Wiltbank et al., 2009; Chandler et al., 2011). Past network relations are important to an effectuator because they essentially constitute the 'Who I know' component of effectual means (Sarasvathy, 2001). However, the understanding of future is essentially different. In effectual networks, the future is controllable but unpredictable (Sarasvathy, 2008: 91), and is open due to the process of co-creating network goals; whereas in goal-driven relations, the future is closed due to their known end goal. Further, effectual networks are those of opportunity rather than networks of trust; although trust can be found empirically in effectual networks, "[t]heoretically speaking, effectual logic does not require any particular assumption about trust ex ante" (Sarasvathy, \& Dew, 2008: 734). Risk cannot be described as an attribute of effectual networking either, because it implies some predictable fact, the negative outcome of which can be quantified with some numerical probability (Knight, 1964). Instead, effectuators follow the principle of affordable loss (Sarasvathy, 2001).

There is a conceptual confusion about what effectual networks really are because they are mentioned in several applications (Kerr \& Coviello, 2019). On the one hand, they are understood as initial relations that start the effectuation process, serving as the 'Whom I know?' part of entrepreneurial means (Sarasvathy, 2001: 253). However, everyone is born into a network of some kind, and the logic behind its formation may not necessarily be non-goal-driven. On the other hand, no matter how effectual networks are formed (through a random chance, in some path dependent fashion, or through deliberate action), they are also understood as the resultant networks of different stakeholders, who a) actually pre-commit something to the new venture creation, and b) participate in the entrepreneurial process by sharing the potential risks and 
benefits of its failure or success (Sarasvathy, \& Dew, 2005: 542; Read, Song \& Smith, 2009: 574). However, the study by Chandler at al. (2011) shows that the criterion for committing something to a new venture is not sufficient to differentiate effectual actions from causal ones, because established precommitments are also present in goal-driven strategic relations. Also, the study by Fischer and Reuber (2011), demonstrates that an actor does not need to be involved in the entrepreneurial process to be a part of the effectual network. Therefore, the two criteria above do not distinguish effectual networks from other entrepreneurial networks. Furthermore, assuming that the stakeholders in the effectual networks can be "any and all interested people" (Wiltbank et al., 2009: 117), including "early partners, customers, suppliers, professional advisors, employees, or the local communities" (Sarasvathy \& Venkataraman, 2011: 126), it is difficult to conceptualize effectual networks based only on the instrumental attributes and functions of actors involved into them.

From the above discussion follows that effectual networks are distinct from the entrepreneurial networks, as they are built on different assumptions. However, theorization of effectual networks is largely undeveloped in the extant research that is partially attributed to the various applications of the concept. Therefore, there is a need for holistic and process-based understanding of effectual networks that would consider not only their structural elements but also the dynamic processes of their formation and their underlying logic. In other words, not only what actors constitute effectual networks but also how these networks come into being and evolve should be examined (Kerr \& Coviello, 2019). Therefore, using the CAS perspective is beneficial because it enables the description of both the dynamic and structural characteristics of systemic entities. In the next subsection, we outline in detail these characteristics of effectual networks, that allow us to view them as CASs.

\subsubsection{Establishing compatibility between effectual networks and CASs}


In this subsection, we synthesize existing effectuation literature discussing (explicitly or implicitly) effectual networks dynamics, and show their compatibility with the CAS view. We organize our discussion around three phases of effectual network development, which we derived based on the existing literature.

\section{Pre-network phase}

The process of effectual network emergence starts at a micro-level, from the means available to entrepreneurs (Sarasvathy, 2001). The unique combination of these means induces the initial rise of effectual relations and has fundamental implications for further changes therein. Consistent with the CAS perspective, the whole deployment of the future effectual network is sensitive to these initial conditions (Schneider \&, Sommers, 2006). Thus, the 'Who I am' set of means would refer to personal identity, various life experiences, educational and professional background etc. The 'What I know' set would relate to everyday life and professional knowledge, expertise and skills. In the context of networking, it may also imply the networking competences needed for new relationship establishment, and their further maintenance. Finally, the 'Whom I know' set would refer to an effectuator's pre-existing and extant relations. These contacts are important for the network formation, because they can be activated for venture purposes and generate resources otherwise unavailable, and other relations through recommendations and forwarding (Read et al., 2017). Notably, effectual means become those when they are cognitively perceived as such (Fischer \& Reuber, 2011). Therefore, potential entrepreneurs scan and evaluate what they have, and what can be useful for future venturing activities. For each entrepreneur, these initial conditions are unique and not fixed; they can change depending on the effectual cycle (Sarasvathy \& Dew, 2005), which explains the following non-linearity of their development as CASs (Kitson et al., 2018).

\section{Formation phase}

Instead of outlining a picture of a network to enter or create, selectively assessing the positions of the most favorable partners, and establishing relations with some but not others, entrepreneurs interact with all and any interested stakeholders (Sarasvathy, \& Dew, 2005; Read et al., 2009; Wiltbank et al., 2009), and even 
strangers (Read et al., 2017: 174). This networking is based on controlling rather than predictive logic (Engel et al., 2017). Read et al. (2017: 173) term these interactions effectual asks, whose nature is very flexible and open allowing entrepreneurs not to fail at very early stages of business creation. Moreover, the degree of this flexibility can be so strong that entrepreneurs may pursue ideas that were not initially in their thoughts, which points to their adaptability (Hogue \& Lord, 2018). Through series of asks entrepreneurs get advice on their ideas, shape and re-shape their future ventures, and co-create the vision of their businesses (Read et al., 2017); this mechanism resembles the establishment of feedback loops in CASs (More \& Ramanujam, 1999; Coleman, 1999). This continuous feedback promotes connectivity (Anderson, 1999) and makes this co-creation process highly iterative. Consistent with the effectual cycle (Sarasvathy \& Dew, 2005), these iterations make the formation of effectual network very sinuous, which corresponds to non-linearity in CASs (Anderson, 1999). Also, the non-goal-driven logic behind networking allows for unexpectedness and the surprise generating mechanism, embodied in the principle of leveraging contingencies (Sarasvathy, 2001). In order to exploit these contingencies, create opportunities from them and be ready for changes, entrepreneurs also need to stay flexible, which requires responsiveness and a "prepared mind" (Dew, 2009; Harmeling \& Sarasvathy, 2011). These processes are similar to adaptability (Hogue \& Lord, 2018) and non-predictable behavior (Harvey \& Reed, 1994) present in CASs. Notably, interactions and negotiations may not progress further and may just remain in an effectual churn, "the continuous looping between social interaction... and the reassessment of means and effects achievable, without progression through the effectuation process" (Fischer \& Reuber, 2011: 10).

\section{Effectual network phase}

When interactions accrue frequency and density, when some ideas gain support through positive feedback and others atrophy under negative feedback, relations that emerged randomly start organizing themselves. This process is congruent with emergent self-organization in CASs that have no internal or external leaders to set goals and control the system (Morel \& Ramanujam, 1999; Chiles et al., 2004). Numerous 
interactions grow into a chain of interactive precommitments (Sarasvathy, 2008: 105); that is, precommitments (actual, not desired or promised) of talent, finance, information, know-how, or time. Notably, the growing number of commitments increases complexity of effectual networks, which leads to an increased uncertainty and unpredictability of relationship outcomes (Simon, 1969; Kauffman, 1993). However, at the same time it serves as an important mechanism of coping with environmental uncertainty (Sarasvathy, 2001: 252). Unlike in goal-oriented networking, effectual entrepreneurs are committed not to the known end-result of networking, but to its open future potential, non-redundancy, and opportunities that new relations may bring (Sarasvathy, \& Dew, 2005; Read et al., 2009; Chandler et al., 2011), which implies flexibility and adaptability featured in CASs (Hogue, \& Lord, 2018). In addition, Sarasvathy (2008: 106) stipulates that " $[t]$ he effectual nature of the commitment process allows the members of the network to proceed as though the universe at any given point in time consisted only of the people at the table - as though the external world is relevant only to the extent it is embodied in their aspirations and abilities". Hence, effectuators rely on immediate reality where the actual actors are known right here and right now.

Furthermore, this non-linear self-organization of effectual networks explains both their stability and dynamism. They are brought about through a process of self-selection, as opposed to the careful culling of partners driven by venture goals (Sarasvathy, \& Dew, 2005; Wiltbank et al., 2009; Read et al., 2009). Partners are interactively self-selected into an effectual network through staking something they can afford to lose (Sarasvathy \& Dew, 2008; Karri \& Goel, 2008). Since no one can predict the success of the venture idea and return on investment, intelligent altruism (Simon, 1993) becomes a critical behavioral assumption for the self-selection. In this process, the entrepreneurial idea serves as an attractor, around which the effectual network organizes itself as CAS (Anderson, 1999).

Coherent with CAS, the emerged system of effectual relations is characterized by the relative stability, strong connectivity and co-evolution of its elements (Anderson, 1999). Each member of the effectual network not only contributes with resources but also sets up constraints regarding who comes on board 
next, and how the entrepreneurial venture can potentially be restructured by adding new stakeholders ${ }^{3}$. This "stacks the deck" and the commitments made create a shared pool of constraints for other choices and commitments (Sarasvathy \& Dew, 2003). While still being self-selected into the emergent effectual network, they also have to fit into the system co-designed before them. Hence, partnerships become less uncertain and the goal better defined, which enables the implementation of more causal decisions (Sarasvathy \& Dew, 2005; Read \& Sarasvathy, 2005).

The effectual network is a co-created complex adaptive system that cannot be centrally coordinated (Sarasvathy \& Dew, 2005: 557); however, it starts producing and reproducing patterns of interactions, reshaping existing environments and creating new ones (Wiltbank et al., 2009). This process of dialectic design may also lead to the further development of new markets (Sarasvathy, 2008; Sarasvathy \& Dew, 2005; Dew et al., 2011). Through an internal reproduction, the new market creates its identity and becomes bounded in some way. These boundaries are porous and difficult to draw because the effectual network evolving into a new market is very open and never finite. As in CASs, its interactions are more important than the boundary, which is at the same time a function and a product of the system. Hence, the boundary does not separate the new market from some outer environment but constitutes it (Cilliers, 2001). Because the boundaries of the emerging new market are constantly renegotiated, its development is compared to the open source phenomenon that allows for "the cooperative shaping of the market rather than a competitive scramble for (predicted to be) valuable resources that drives industry dynamics" (Read et al., 2009: 14).

The above discussion shows that effectual networks represent a distinct type of entrepreneurial networks; they are complex and adaptive systems of relations formed under conditions of uncertainty through engaging into the effectual process and following the principles of means driven action, interactions with all interested stakeholders, affordable loss, and leveraging contingencies. Also, the principles of CASs

\footnotetext{
${ }^{3}$ This happens due to the nature of an effectual commitment, which is defined as "a self-imposed non-negotiable constraint that stacks the deck in favor of or against specific future choices" (Sarasvathy \& Dew, 2003: 2).
} 
are visible in effectual networks, which reveals their theoretical compatibility. Table 1 below summarizes points of contiguity between CASs and effectual networks and demonstrates their differences. It also sets up the basis for our empirical study, which is discussed in the next section.

\section{Insert Table 1 here}

\section{METHODOLOGY}

\subsection{Rationale behind the research design}

The research design of this study is driven by the inductive exploration ${ }^{4}$ of effectual networks as CASs. Our study follows multiple-case study strategy, which suits its theory-building purpose (Eisenhardt, \& Graebner, 2007). Also, the exploratory course of this study fits the qualitative methodology because it does not imply any hypothesis testing. Additionally, our study focuses on dynamic characteristics of effectual networks; qualitative methods are more appropriate to capture the processes and mechanisms of change in complex systems (Cassell, \& Symon, 1994; Stake, 1995). Also, the adaptive design and open-ended nature of the case study strategy (Yin, 2014) allows for iterative theoretical and empirical choices, which is relevant to our cross-disciplinary and exploratory study. Furthermore, case-study strategy allows for the attention to context, which is important for the network perspective of our research (Halinen \& Törnroos, 2005). Besides, qualitative research has a better fit with developing theories (Edmondson \& Mcmanus, 2007), such as effectuation (Arend et al., 2015; Read et al., 2016; Matalamäki, 2017).

\subsection{Case selection}

According to Yin (2014), information from several sources on the phenomenon provides more comprehensive understanding without chance associations. In addition, Eisenhart (1989) recommends including four to ten cases in multiple-case research. The amount of data from this many cases is enough

\footnotetext{
${ }^{4}$ We adhere to the idea that induction and deduction are not exclusive logics of inference, and no study can genuinely separate them (Parkhe, 1993; Eisenhardt, 1989). Thus, our conceptual part has some elements of deduction needed for establishing theoretical basis; however, induction dominates in our study because the main contribution comes from theory building process of developing the model and propositions.
} 
for analytical generalization but relatively easy to cope with in terms of volume (Yin, 2014; Patton, 2015). Following these lines, this study focuses on the entrepreneurial networks of ten startup firms from Finland.

These case firms were selected adhering to purposeful sampling coupled with replication logic (Fletcher \& Plakoyiannaki, 2011; Yin, 2014). Given that effectuation logic is especially present at the very initial stages of business development (Sarasvathy, 2001; Sarasvathy \& Dew, 2005), we selected private startups at the very early entrepreneurial stage to ensure sought processes (by the time of the data collection, the chosen firms had just launched their product or were founded not more than three years ago). We did not apply the criterion of expertise because recent studies show that also novice unexperienced entrepreneurs engage into effectuation (Laskovaya et al., 2017). To assure equivalence and comparability between the cases (Patton, 2015; Yin, 2014), we chose the startups from the ICT/smart-phone-applications industry. Even though they targeted different customer needs (some developed applications for spray printing, others for video content or food delivery), their final product was the same, a web-based application; hence, our sampling qualifies as homogeneous. However, in making this choice, we do not claim that mechanisms behind entrepreneurial networking and effectual network formation vary greatly across industries.

The study setting for our research has been achieved by attending two entrepreneurial events, namely Slush (www.slush.org) and a workshop organized by Arctic Start Up, a Helsinki-based entrepreneurship support organization (www.arcticstartup.com). During these events, the lead author of this article invited 42 entrepreneurs to participate in this study. After these initial meetings, the potential participants were sent e-mails with a short description of the research project and requests for interview meetings. Ten entrepreneurs agreed to participate in the study. Using snow-ball sampling, we also got access to the other founders of their teams. 


\subsection{Data collection}

We conducted 23 personal interviews with members of entrepreneurial teams (see Table 2), i.e. with all the founders of the studied startups. The interviews were conducted during December 2016 and January 2017. The interviews were semi-structured to reveal the situational context and respondents' subjective opinions on the unexplored phenomenon of effectual networks (Gummesson, 2000; Stake, 1995; Yin, 2014). Also, this method provides space for other related topics to emerge during the conversation (Patton, 2015). The interview guide used in this study comprised open-ended questions because they permit the informant to use their own terms (Patton, 2015). Our interviewees did not receive the interview guide in advance.

The dynamic processes within effectual networks were grasped by conducting an event-based study. This method allows us to see how certain events (e.g., getting the first ideas for a future business, inception, launching a product) trigger changes in network relations. The techniques employed were analytical schemes and event trajectories that allowed us to answer not only what changes happened in our informants' networks but also why they happened (Halinen et al., 2013). In many instances, these events were identified by our informants along with their stories; thus, we allowed for their own interpretations of what events were important in the timeline of their ventures. Along with the conversations, four respondents made some drawings presenting their network relations visually and assisted in forming the interview protocols. These drawings were attached to the interview notes and used later in data transcription and analysis; they allowed us to secure all the important nuances about informants' relations. Each interview lasted 45-90 minutes, was recorded and then transcribed verbatim. The informants were made aware they were being recorded. Both data collection and interview transcription were performed by the lead author. The interviews resulted in 1507 minutes of audio records and 323 pages of transcribed text (Times New Roman, 12-point, line spacing 1.15). In order to achieve methodological rigor and adequacy of our research procedures, we documented the entire data collection process in a research diary. We made notes on important issues 
(interview setting, a general atmosphere of a conversation, post-interview talks etc.). Also, to ensure the accuracy of our transcripts, we returned them to the interviewees for verification and follow-up questions.

Besides the primary data sources, we incorporated information from websites, blogs, social media profiles and various press releases, about the interviewees, their startups, products, main clients and suppliers. We consistently used these data to prepare for interviews and double-check the information obtained from the records (Cassel \& Symon, 1994). After the interviews, we used these sources to verify the obtained information. For instance, many interviews contained stories about how the informants established their ventures; if possible, we compared this information with that available on-line. Also, we checked the content of relationships our informants mentioned during interviews through social media sites. Overall, combining interviews and secondary data strengthened the validity and reliability of our research.

\section{Insert Table 2 here}

\subsection{Data analysis}

In this study, the unit of analysis is both entrepreneurs and their startups. In small entrepreneurial firms, the individual and organizational levels are the same. For instance, Hite and Hesterly (2001) show that entrepreneurs' networks overlap with those of their ventures. Also, Johannisson (1998: 300) indicates that "since the entrepreneur epitomizes the small firm and its physical and human resources, the individual and the organization as units of analysis coincide."

As is natural in qualitative research (Yin, 2014), the informal data analysis started during the interviews; for example, the interviewer, who is also the lead authors of this article, posed clarifying questions and connected certain events with the startups' network development. Further formal data analysis after the interviews involved both authors to avoid ambiguity in interpretations. In the manual analysis, we used within-case and cross-case displays in the form of field notes, matrices, tables and networks to find patterns and themes in the data (Miles \& Huberman, 1994). The electronic data analysis was assisted by NVivo 11. The themes identified in the literature served as a basis for a priori codes, which were then identified in the 
transcripts (see Table 3). Using Fisher's (2012) criteria for causation and effectuation, we were able to distinguish effectual logic in entrepreneurs' networking and focus on it as the primary focus of our study. We also followed Gioia et al. (2013), inferring concepts, themes and aggregate theoretical dimensions from the raw data excerpts. Guided by our theoretical discussion, we organized our data analysis around three phases of effectual network development and looked at this process from the perspective of a focal entrepreneur. The qualitative strategy of our study enabled emerging concepts and themes to be identified in the data. For example, we were able to see evidence of other types of effectual means than just available means.

Consistent with the CAS perspective of our study, we distinguished between structural and dynamic factors for each phase of effectual network formation. We identified structural elements by decomposing complex units of effectual networks into more simple and indivisible elements (e.g., effectual asks, commitments, established connections). Capturing the dynamics of effectual network was a two-fold process. Network development through the phases identified in the literature was detected by tracing it backwards into the past, as suggested by Bizzi and Langley (2012). Interview narratives contained information on events and incidents that triggered change in networks. We analyzed these events by applying the tools of analytical schemas and event trajectories (Halinen et al., 2013) to connect them with processual changes in networks. We recognized micro-dynamics adherent to each phase (e.g., scanning for and realizing means as dynamic factors within pre-network phases), which enabled us to demonstrate micro-processes within the overall flow of effectual network emergence. Table 3 demonstrates the structure of our data and the inference from the first-order concepts to the second-order themes and the aggregate theoretical dimensions (see also Tables 4, 5 and 6); it also integrates all concepts and themes, moving further towards the development of our final model (Figure 1).

Insert Table 3 here 


\section{RESULTS AND DISCUSSIONS}

The aim of our study is to apply CASs perspective to understanding effectual networks and to identify dynamic and structural entrepreneur-related factors that influence their emergence. We frame the presentation of our results and their discussion around the three phases of effectual network emergence.

\subsection{Pre-network phase}

Our analysis shows (see Table 3 and Figure 1), that this phase can be characterized by important initial conditions (Schneider, \& Sommers, 2006) that determine future shapes and crystallizations of effectual networks. These initial conditions are not only structural components setting up the basis for future systems of effectual network relations, but also triggers for dynamic processes within them. Here, we refer to entrepreneurial means available to a potential business founder (Sarasvathy, 2001; 2008) and which they identified through the process of scanning for means.

However, just having means has not been enough to trigger the process of effectual network emergence. Consistent with Fischer and Reuber (2011), we found the dynamic cognitive activity of realizing means through in-depth self-reflection and comparing yourself with others was an important factor affecting the start of the entire venture creation and effectual network development. As proposed by Sarasvathy (2001; 2008), some existing relations that entrepreneurs identified as the "Whom-I-know" part of the means became a foundation of the future network of relations. Following Read et al. (2017), we relate them to the pre-network phase, because they are not newly and actively established connections but the given relations that have become initial preconditions for future networks. The interviewed entrepreneurs identified these existing contacts as the first potential stakeholders to interact with and commence the employment of available means. Our interviews also pointed to another significant structural factor influencing the setting of effectual networks. Consistently, the setting of effectual networks has been highly dependent on the entrepreneurs' willingness to proceed further with set of means cognitively identified as useful for future 
entrepreneurial endeavors. This motivation triggered the further networking, identifying entrepreneurial opportunities and growing effectual networks.

Also, our findings point not only to the means described in the effectuation research (Sarasvathy, 2001; Read et al., 2017), which we term actual means, but also to the other types of means. Thus, we could also distinguish 1) dormant means or sleeping relations that entrepreneurs had but did not need at the moment and kept reserved in an "inventory" for future activation; 2) non-functional means or contacts entrepreneurs had but could not use at the moment for various reasons; 3) latent means or relations entrepreneurs had but did not perceive as valuable for entrepreneurial purposes. Interestingly, entrepreneurs could also perceive the gaps in their existing contacts and identify 4) unavailable means or relations they do not have but would like to have. These gaps can either hinder or lock further networking and venturing processes or can motivate them to re-scan for available means, through which dormant, non-functional and latent means could be shifted into the category of actual means. Alternatively, entrepreneurs might start actively establishing new relations with various new stakeholders and, thus, expand the set of available means. This is a cross-phase activity linking Pre-network and Formation phases.

\section{Insert Table 4 here}

\subsection{Formation}

Our analysis demonstrates (see Table 4) that the actual formation of effectual networks starts when entrepreneurs begin actively networking with all and any stakeholders and sharing their ideas, which corresponds with Sarasvathy and Dew (2005), Read et al. (2009), and Wiltbank et al. (2009). This networking is a distinctive dynamic factor that fosters the deployment of effectual networks, even though it increases complexity and consequently, uncertainty of developing relations. In this phase, the initial effectual asks are important structural factors because they are already conscious attempts to collect opinions about inceptive entrepreneurial ideas. Consistent with previous research (Dew, \& Sarasvathy, 2007; Sarasvathy, \& Dew, 2008), these networking and asks result in rather specific stakes or offers an 
entrepreneur can afford to lose, which initiates a reciprocal mechanism in counterparts, who also assess their affordable loss. These stakes can be in the simple form of time spent with potential partners and/or shared ideas about potential business. Alongside these asks and initial interactions, the focal entrepreneur peers at potential partners and gets to know them through their counter suggestions. These feedback loops serve as an important mechanism of decreasing uncertainty in effectual networks.

In addition, we have uncovered another important dynamic factor, namely establishing connectivity among interactions. Thus, entrepreneurs begin to relate and link together unbound and unrelated interactions that become concentrated around them, and their entrepreneurial idea as an attractor. In this phase, the idea may not be fully-fledged and final; however, it needs to be strong enough to attract stakeholders. Furthermore, our interviews demonstrated that achieving a critical mass of interactions is one of the decisive dynamic factors in effectual network formation. This micro-process also constitutes an opportunity for the entrepreneurial idea to be proven reasonable.

Insert Table 5 here

\subsection{Effectual network phase}

In line with Sarasvathy and Dew (2005), Sarasvathy (2001, 2008), and Read et al. (2009), we have found (see Table 6) that the emergence of effectual networks also depends on whether effectual asks and stakes evolve into actual commitments (a structural factor of effectual network development) and, thus, initiate a self-selection of stakeholders into the effectual network (a dynamic factor). Indeed, some entrepreneurs may not go beyond asking, resulting perhaps in no actual commitments of money, expertise, and/or time.

Consistent with the previous phase, entrepreneurs and their ideas remain the main attractor; this attractor consolidates the network as a system, as suggested by Anderson (1999). Actual commitments made around and about the idea may continue to shape it. Also, this phase often coincides with an event of the establishment of the startup as a legal entity. Unlike in the previous phase, the entrepreneurial idea gains more concrete contours of a venture as a business unit with more specified functions and tasks. Naturally, 
actual commitments and their fulfillment determine whether relations are workable and what established connections the entrepreneurs have. Consistent with Sarasvathy and Dew (2003), these existing relations, in turn, will define what new connections will be added to the emergent network. Also, maintaining established relations through regular interactions and, at the same time, adjusting the fit between established and new connections become crucial dynamic factors of effectual network development.

Further, the resulting relations gain consistency and continuity. Consistent with CASs (Chiles, Meyer, \& Hench, 2004), they start reproducing themselves through self-organized patterns of interactions and communication habits developed by counterparts. These patterns may become apparent in the form of the set regularities of meetings, framed behavior during and outside them, working standards, and norms among partners. However, this does not mean that effectual networks lose flexibility and become rigid. Because the availability of various stakeholders (together with their means and commitments) gives room for maneuver, the network remains adaptive and responsive to external change.

Even though our empirical entrepreneur-centric study does not allow making an inference about effectual networks at a market-level of analysis, based on our theoretical discussion, we would speculate that the self-organized patterns of interactions let new effectual networks grow into new markets (Sarasvathy \& Dew, 2005; Read et al., 2009; Dew et al., 2011). However, the empirical testing of this idea would require another study at a higher level of analysis.

\section{Insert Table 6 here}

We summarize the dynamic and structural factors of effectual network development in Table 7 below. Notably, both dynamic and structural factors unfold in effectual networks in a self-reinforcing and tightly inter-related manner. In other words, dynamic processes within them cannot be understood without structural components, and the nature of these structural elements can be understood only through their developmental dynamics. Additionally, our discussion above allows for deriving propositions about 
effectual networks as CASs. These propositions link together their structure and dynamics. Table 7 groups them into main-effect and moderating/mediating propositions.

\section{Insert Table 7 here}

\section{Insert Table 8 here}

Additionally, based on our findings and discussion, we develop a process-system model that visually shows the dynamics of effectual network emergence through three stages (see Figure 1). The model does not depict an effectual network at a certain point in time, creating a static snapshot; rather, our propositions and the model allow for tracing the connection between the elements of the network and reveal the process of becoming of an effectual network. Also, the model allows for connecting the stages of network formation with respective units of analysis. Thus, the pre-network phase emphasizes the micro-level of individual entrepreneurs and their means; the formation phase shifts the focus to interactions between entrepreneurs and stakeholders; the effectual network phase focuses on a venture as a unit of analysis. Additionally, this perspective assists in capturing emerging, as well as disappearing, network elements (such as uninterested stakeholders or/and negotiations that do not become embodied in actual commitments in our model), enabling us to understand and explain how it evolves. Stemming from our theoretical discussion, we also propose that effectual networks develop further into new markets (Sarasvathy \& Dew, 2005; Read et al., 2009; Dew et al., 2011). In Figure 1, we depict this with a dotted arrow, because our entrepreneur-centric data does not provide clear evidence for it; exploring how effectual networks grow into new markets would imply more complex inter-firm level of analysis and require another study.

\section{Insert Figure 1 here}

Because any model seeks to simplify reality and reduce complexity by omitting something, it is impossible to have a perfect model of a complex system that would keep track of all simultaneous, non-linear interactions between its components (Cilliers, 2001). However, our derived propositions describe fully the intricate interactions of the model components. Therefore, the model itself serves as an illustrative and 
explanatory tool to complement our propositions and to contemplate effectual networks in a more complete manner. Also, the suggested phases in the process of their emergence and related system characteristics are probabilistic rather than deterministic.

\section{CONCLUSIONS}

Our study has shown effectual networks through the lens of CASs and demonstrated entrepreneur-related structural and dynamic factors of their development. We have developed several propositions and a processsystem model that demonstrate the interdependence of these factors along the three phases of effectual network emergence, namely pre-network, formation, and effectual network. Our study builds on the dynamic process model of entrepreneurial networking under uncertainty developed by Engel et al. (2017). Their conceptual work is an important step forward in understanding the effectual logic of networking where the focal entrepreneur has the main agency. We also take a process view; however, our empirical study offers a different and novel approach. Adapting CAS perspective allows grasping not only the dynamics of effectual network formation but also seeing it at a system level and capture its structural characteristics. Importantly, we also show various inter-relations between the structure and dynamics along the effectual network emergence. Engel et al. (2017) frame their model around cycles of networking and cycles of goal convergence and means expansion; also, their level of analysis - a focal entrepreneur - does not change. Our model, in turn, builds on stages of effectual network formation and shows the move from micro levels of analysis (entrepreneurial means) towards higher ones (a new venture). Hence, our perspective allows zooming into the micro-dynamics of network emergence and at the same time zooming out and see them as a part of a bigger system. Additionally, while Engel et al. (2017) connect entrepreneurial networking with uncertainty, the CAS perspective suggests an important link between conditions of complexity and uncertainty. Overall, our work serves as an important stepping stone to advance effectuation and converge it with complexity theory. We now go beyond our empirical results and speculate on new possibilities and implications of complexity theory for the effectuation research. 


\subsection{Network emergence under conditions of complexity and uncertainty}

Our article shows that complexity theory and effectuation share a common problem space, uncertainty, which stems from inability to predict. The difference they exhibit, however, is that for complexity theory unpredictability comes from too many interactions between perhaps known parameters, their diversity, and the absence of cause-and-effect chains between them; whereas for effectuation, uncertainty results from unknown and unknowable parameters and their interactions. In the effectual networking context, the adopted CAS perspective allows proposing that involving numerous stakeholders increases the complexity of the process, because more parameters begin to interact and more information asymmetry is created. This, in turn, leads to unpredictability and uncertainty. However, this early engagement of the stakeholders and their dynamic connectivity can mitigate the effects of uncertainty; concurrent processes of relationship expansion and contraction enable adaptive dynamics, responsiveness, and co-creation, which are crucial to effectual commitments and acting upon leveraged contingencies. Hence, paradoxically, the complexity of effectual relations is both a source of uncertainty and a remedy for developing entrepreneurial relations under these uncertain conditions.

Given that effectuation and causation are not mutually exclusive logics (Smolka et al., 2016), our findings can be taken further to investigate the role of complexity not only in relation to the effectual strategies of entrepreneurs but also in their combination with causation. Aiming for predictability, goal orientation, and certainty, causal strategies may lead to lower levels of complexity and less uncertainty; at the same time, this may cause lack of responsiveness, openness to the unexpected, and undeveloped opportunities. Conversely, effectual strategies result in increased complexity, which allows for flexibility, efficient reactions to change, and control over uncertainty. Hence, future research may examine the levels of complexity and uncertainty when both causation and effectuation are present.

\subsection{Clarifying the concept of effectual control}


Controlling the unpredictable future is one of the key principles of effectuation (Sarasvathy, 2001). Read et al. (2016: 531) claim that the nature of this control requires more research attention. Our CAS perspective deepens the understanding of effectual control. We show that entrepreneurs can control an unpredictable future by increasing the complexity of their relations, which paradoxically allows them to cope with uncertainty. We also indicate the adaptive, feedback-based and distributed nature of this control. Our model offers an important component of effectual control in networks, namely an attractor, which is represented by an entrepreneur and his/her entrepreneurial idea. Our propositions show that being uncertain, multidimensional and changing systems, effectual networks become self-organized through interconnections between committed stakeholders around attractors without any central controlling body.

Future studies can extend our findings and examine the possible drawbacks of this distributed effectual control in situations where some stakeholders wish to maximize their benefit. Assuming that causal and effectual reasoning are combined in entrepreneurial actions (Sarasvathy, 2001; Smolka et al., 2016), the future research can also examine how effectual control co-exists with causal control at different levels, and whether this co-existence is harmonious and productive or conflicting and destructive. In addition, scholars could adopt a dynamic perspective on effectual control and see whether it changes from distributed to more localized (e.g., around one or several attractors), and asymmetric along the stages of venture development.

\subsection{Understanding the mechanism for the acquisition of effectual expertise}

Read et al. (2016: 531) stipulate that our understanding of how decision-makers acquire effectual expertise is insufficient, and scholars need to examine specifically the role of deliberate practices in acquiring this expertise. Our model shows that entrepreneurs acquire effectual expertise through positive and negative feedback loops to and from various stakeholders; this iterative looping back and forth is a strong selfreinforcing learning mechanism. Thus, the acquired expertise becomes the basis for the next feedback loop, which, in turn, results in yet further increased expertise. Following effectual logic entrepreneurs deliberately leverage a variety of interactions in order to gain effectual expertise, increase chances for contingencies 
and thus secure conditions for new opportunities. This is closely linked to the theory of expertise by Simon and Chase (1973); they conclude that expertise is gradually gained through acquiring patterns and knowledge on how to react in certain situations; later, future experts store memories of their past actions and reproduce those actions in similar situations. The difference with effectual expertise is, however, that under conditions of complexity and uncertainty the decision-making circumstances will not be similar, and the re-production of past actions may not be relevant. Yet, addressing all and any stakeholders through series of effectual asks and getting feedback through positive and negative loops may become a deliberate and even routinized pattern of gaining effectual expertise, which is consistent with expertise acquisition literature (Ericsson, 2018). Stemming from these results, the future research can use the CAS perspective to explore system-level acquisition of effectual expertise, for example, at a unit or corporate level. To date, effectuation studies have been concentrated mainly on the cognitive, individual-centric mechanisms of acting and reasoning. However, little is known about how firms as systemic entities can develop effectual expertise and, more importantly, obtain the capability to combine it with causal strategies. Complexity theory and its more specific principles of adaptability, co-evolution and connectivity can be a useful tool for research in this direction.

\subsection{Understanding the transformation of effectual means into causal resources}

Besides, our findings open up and pluralize the concept of effectual means, showing that entrepreneurs not only consider the actual means at hand but also scan for dormant, non-functional, latent, and unavailable means. Differentiation between these different types of means can be useful to investigate the transformation of effectual means into causal resources (Read et al., 2016). Realization of what entrepreneurs have allows them to understand what they do not have but need to have. This, in turn, starts another micro-process of identifying a need and developing an action plan to fulfil that need (What should I do to get what I do not have? How can I use what I have to get what I do not have?), which resembles a 
goal-driven causal process. Future studies can examine in more detail this mechanism of how effectual means at hand become strategic resources to satisfy the need.

\section{PRACTICAL IMPLICATIONS}

Our study shows that effectual reasoning is suited to entrepreneurs establishing relations under conditions of uncertainty and complexity, which is different from purposeful and instrumental networking. By differentiating between entrepreneur-related dynamic and structural factors, as well as by elaborating the process-system model of effectual networks, we open up how effectual networking is linked with the process of resource leveraging. In the pre-network phase, entrepreneurs can compile a portfolio of actual and unavailable means. It enables important connections between different types of means and further actions; for example, how unavailable means can be gained by utilizing actual means or addressing others through effectual asks. Additionally, the model may envision various scenarios of how unavailable means can influence the process of network formation and venture development, in case they are gained or not gained. This would also facilitate entrepreneurial opportunity identification and assist in decision-making along the venture creation process. Moreover, the process-system model of effectual networks points towards the need to identify the existing relations, the "Whom-I-know" part of the means, as these represent essential conditions to which the future network is highly sensitive. At the formation phase, it is important for entrepreneurs to interact with any and all stakeholders and stay open to unexpected connections. It would increase the complexity of relations, help to deal with uncertainty, and bring new opportunities in a very organic way. These intensive interactions could help to achieve a critical mass of interactions, enable connectivity, and testing initial entrepreneurial ideas with various stakeholders. In the formation stage, entrepreneurs can utilize an entrepreneurial idea, or an attractor, to group unbound and unrelated interactions, thereby fostering network development. In other words, the entrepreneurial idea can help create a pool of interested stakeholders. Further, at the network stage, entrepreneurs should pay due attention to maintaining the established workable relations and fitting new ones into the emergent network. 


\section{LIMITATIONS}

The primary focus of our study is effectual networks. However, we are aware of the growing number of studies examining the interdependency and simultaneity of effectuation and causation (Perry et al., 2012; Reymen et al., 2015; Smolka et al., 2016). Hence, our study can be criticized for not viewing a broader picture and not connecting effectual network mechanisms with more causal ones. Our argument concerning this potential criticism is that in order to understand their co-existence, effectual networks need to be conceptualized and described properly. Therefore, our study can serve as an initial step towards further research on co-existence of effectual and causal networks and how they interflow into entrepreneurial networks.

\section{REFERENCES}

Anderson, P. (1999). Complexity theory and organization science. Organization Science 10(3), $216-232$.

Anderson, P., Meyer, A., Eisenhardt, K., Carley, K., \& Pettigrew, A. (1999). Introduction to the special issue: Applications of complexity theory to organization science. Organization Science 10(3): 233236.

Alsos, G.A., Clausen, T.H., Mauer, R., Read, S. \& Sarasvathy, S. (2019). Effectual exchange: From entrepreneurship to the disciplines and beyond. Small Business Economics, https://doi.org/10.1007/s11187-019-00146-9

Arend, R. J., Sarooghi, H., \& Burkemper, A. (2015). Effectuation as ineffectual? Applying the 3E theoryassessment framework to a proposed new theory of entrepreneurship. Academy of Management Review 40(4), 630-651.

Bizzi, L., \& Langley, A. (2012). Studying processes in and around networks. Industrial Marketing Management 41, 224-234.

Burnes, B. (2005). Complexity theories and organizational change. International Journal of Management Reviews 7(2): 73-90.

Burns, B.L., Barney, J.B., Angus, R.W. \& Herrick, H.N. (2016). Enrolling stakeholders under conditions of risk and uncertainty. Strategic Entrepreneurship Journal 10(1), 97-106.

Burt, R. (1995). Structural Holes: The Social Structure of Competition. Harvard University Press: Cambridge, MA.

Burt, R. (2004). Structural holes and good ideas. American Journal of Sociology, 110(20), 349-399.

Cassell, C., \& Symon, G. (1994). Qualitative Methods in Organizational Research: Practical Guide. London: SAGE Publications.

Chandler, G.N., D.R. DeTienne, A. McKelvie, \& T.V. Mumford (2011). Causation and effectuation process: A validation study. Journal of Business Venturing 26(3), 375-390.

Chiles, T., Meyer, A. \& Hench, T. (2004). Organizational emergence: The origin and transformation of Branson, Missouri' musical theaters. Organization Science 15(5): 499-519.

Choi, T. Y., Dooley, K. J., \& Rungtusanatham, M. (2001). Supply networks and complex adaptive systems: Control versus emergence. Journal of Operations Management 19, 351-366. 
Cilliers, P. (2001). Boundaries, hierarchies and networks in complex systems. International Journal of Innovation Management 5(2), 135-147.

Coleman, H. J. (1999). What enables self-organizing behavior in businesses. Emergence 1: 33-49.

Coviello, N. E. (2006). The network dynamics of international new ventures. Journal of International Business Studies 37(5), 713-731.

Dew, N. (2009). Serendipity in entrepreneurship. Organization Studies 30, 735-753.

Dew, N., Read, S., Sarasvathy, S.D. \& Wiltbank, R. (2011). On the entrepreneurial genesis of new markets: Effectual transformation versus causal search and selection. Journal of Evolutionary Economics 21, 231-253.

Diánez-González, J. P., \& Camelo-Ordaz, C. (In press). The influence of the structure of social networks on academic spin-offs' entrepreneurial orientation. Industrial Marketing Management, https://doi.org/10.1016/j.indmarman.2017.12.009.

Dooley, K. (1996). A Nominal Definition of Complex Adaptive Systems. The Chaos Network 8(1) 2 -3.

Dooley, K. J., \& Van de Ven, A. H. (1999). Explaining complex system dynamics. Organization Science 10(3): 358-372.

Drazin, R., \& Sandelands, L. (1992). Autogenesis: A perspective on the process of organizing. Organization Science 3(2), 230-249.

Edmondson, A., \& S. McManus (2007). Methodological fit in management field research. Academy of Management Review 32(4), 1155-1179.

Eisenhart, K. (1989). Building Theories from Case Study Research. Academy of Management Review 14(4), 532-550.

Eisenhart, K., \& Graebner, M. (2007). Theory building from cases: Opportunities and challenges. Academy of Management Journal 50 (1), 25-32.

Engel, Y., Kaandorp, M. \& Elfring, T. (2017). Toward a dynamic process model of entrepreneurial networking under uncertainty. Journal of Business Venturing 32, 35-51.

Ericsson, K. (2018). The Differential Influence of Experience, Practice, and Deliberate Practice on the Development of Superior Individual Performance of Experts. In K. Ericsson, R. Hoffman, A. Kozbelt, \& A. Williams (Eds.), The Cambridge Handbook of Expertise and Expert Performance (Cambridge Handbooks in Psychology, pp. 745-769). Cambridge: Cambridge University Press. doi:10.1017/9781316480748.038

Fischer, E., \& Reuber, A.R. (2011). Social interaction via new social media: (How) can interactions on Twitter affect effectual thinking and behavior? Journal of Business Venturing 26(1), 477-493.

Fisher, G. (2012). Effectuation, causation, and bricolage: a behavioral comparison of emerging theories in entrepreneurship research. Entrepreneurship Theory and Practice, 36(5), 1019-1051.

Fletcher, M., \& E. Plakoyiannaki (2011). Case selection in international business: key issues and common misconceptions. In: Rethinking the Case Study in International Business and Management Research. Ed. R. Piekkari, and C. Welch. Cheltenham, UK: Edward Elgar Publishing, 171-190.

Gioia, D.A., Corley, K.G., \& Hamilton, A.L. 2013. Seeking qualitative rigor in inductive research: Notes on Gioia methodology. Organizational Research Methods, 16(1), 15-31.

Granovetter, M. (1973). The strength of weak ties. American Journal of Sociology, 78(6), 1360-1380.

Granovetter, M. (1985). Economic action and social structure: The problem of embeddedness. American Journal of Sociology, 91(3), 481-510.

Greve, A., \& Salaff, J.W. (2003). Social Networks and Entrepreneurship. Entrepreneurship Theory and Practice, 28(1), 1-22.

Gummesson, E. (2000). Qualitative methods in management research. 2nd ed. Thousand Oaks, CA: SAGE Publications.

Gupta, V., Chiles, T., \& McMullen, J. (2016). A process perspective on evaluating and conducting effectual entrepreneurship research. Academy of Management Review 41(3), 540-544. 
Håkansson, H. \& Ford, D. (2002). How should companies interact in business networks? Journal of Business Research, 55(2), 133-139.

Håkansson, H. \& Snehota, I. (1995). Developing Relations in Business Networks. Thompson, London.

Halinen, A., \& Törnroos, J-Å. (2005). Using case methods in study of contemporary business networks. Journal of Business Research 58 (9), 1285-1297.

Halinen, A., Törnroos, J-Å., \& Elo, M. (2013). Network process analysis: An event-based approach to study business network dynamics. Industrial Marketing Management 42, 1213-1222.

Hansen, E. L. (1995). Entrepreneurial Networks and New Organizations Growth. Entrepreneurship Theory and Practice, 19(4), 7-19.

Harmeling, S., \& Sarasvathy, S. (2011). When contingency is a resource: Educating entrepreneurs in Balkans, The Bronx, and beyond. Entrepreneurship Theory and Practice 37(4), 713-744.

Harvey, D., \& Reed, M. (1994). The Evolution of Dissipative Social Systems. Journal of Social and Evolutionary Systems 17(4) 371-411.

Hite, J.M., \& Hesterly, W.S. (2001). The evolution of firm networks: from emergence to early growth. Strategic Management Journal 22(3), 275-286.

Hoang, H., \& Antoncic, B. (2003). Network-based research in entrepreneurship: A critical view. Journal of Business Venturing, 18(2), 165-187.

Hogue, M., \& Lord, R. (2007). A multilevel, complexity theory approach to understanding gender bias in leadership. The Leadership Quarterly 18: 370-390.

Hunterhuber, H.H., \& Hirsch, A. (1998). Starting Up a Strategic Network. Thunderbird International Business Review, 40(3), 185-207.

Jack, S. (2010). Approaches to Studying Networks: Implications and Outcomes. Journal of Business Venturing 25(1), 120-137.

Jack, S., Drakapulou Dodd, S., \& Anderson, A.R. (2008). Change and the development of entrepreneurial networks over time: A processual perspective. Entrepreneurship and Regional Development, 20, 125159.

Jack, S., Moult, S., Anderson, A. \& Dodd, S. (2010). An entrepreneurial network evolving: Patterns of change. International Small Business Journal 28(4), 315-337.

Jarillo, J.C. (1988). On Strategic Networks. Strategic Management Journal, 9(1), 31-41.

Johannisson, B. (1998). Personal networks in emerging knowledge-based firms: spatial and functional patterns. Entrepreneurship and Regional Development, 10(4), 297-312.

Jiang, Y., \& Ruling, C.-C. (2019). Opening the black box of effectuation processes: Characteristics and dominant types. Entrepreneurship Theory and Practice, 43(1), 171-202.

Karri, R., \& Goel, S. (2008). Effectuation and over-trust: Response to Sarasvathy and Dew. Entrepreneurship Theory and Practice, 32(4), 739-748.

Kauffman, S. A. (1991). Antichaos and adaptation. Scientific American 265(2), 78-84.

Kauffman, S. A. (1993). Origins of order: Self-organization and selection in evolution. Oxford University Press. Oxford, England.

Kerr, J. \& Coviello, N. (2019). Formation and constitution of effectual networks: A systematic review and synthesis. International Journal of Management Reviews. DOI: 10.1111/ijmr.12194

Kilduff, M., \& Tsai, W. (2003). Social Networks and Organizations. Sage Publications: London.

Kitson, A., Brook, A., Harvey, G., Jordan, Z., Marshall, R., O’Shea, R., \& Wilson, D. (2018). Using complexity and network concepts to inform healthcare knowledge translation. International Journal of Health Policy and Management 7(3): 231-243.

Knight, F.H. (1964) Risk, Uncertainty and Profit. Augustus M. Kelley, New York, USA.

Koon, B., \& Low, H. (1997). Managing business relations and positions in industrial networks. Industrial Marketing Management, 26, 189-202. 
Larson, A. (1991). Partner Networks: Leveraging external ties to improve entrepreneurial performance. Journal of Business Venturing, 6(3), 173-188.

Larson, A., \& Starr, J.A. (1993). A network model of organization formation. Entrepreneurship: Theory and Practice, 17(2), 5-15.

Laskovaya, A., Shirokova, G., Morris, M. (2017). National culture, effectuation, and new venture performance: global evidence from student entrepreneurs. Small Business Economics 49, 687-709.

Lechner, C., \& Dowling, M. (2003). Firm Networks: External Relations as a Source for the Growth and Competitiveness of Entrepreneurial Firms. Entrepreneurship and Regional Development, 15(1), 1-26.

Lewin, R. (1992). Complexity: Life at the Edge of Chaos. MacMillan, New York.

Lichtenstein, B. B., Carter, N. M., Dooley, K. J., \& Gartner, W. B. (2007). Complexity dynamics of nascent entrepreneurship. Journal of Business Venturing 22: 236-261.

Lissack, M.R. (1999). Complexity: the science, its vocabulary, and its relation to organizations. Emergence 1(1): 110-125.

Maguire, S., McKelvey, B., Mirabeau, L., \& Öztas, N. (2006). Complexity science and organization studies. In: Clegg, S., Hardy, C., Lawrence, T. \& Nord, W. R. (eds), The SAGE Handbook of Organization Studies. London, Sage, 165-214.

Matalamäki, M.J. (2017). Effectuation, an emerging theory of entrepreneurship: Towards a mature stage of the development. Journal of Small Business and Enterprise Development 24(4), 928-949.

McElroy, M. (2000). Integrating complexity theory, knowledge management and organizational learning. Journal of Knowledge Management 4(3): 195-203.

McKelvey, B. (2004). Towards a complexity science of entrepreneurship. Journal of Business Venturing 19(3): 313-29.

McKelvie, A., Chandler, G., DeTienne, D., \& Johansson, A. (2019). The measurement of effectuation: Highlighting research tensions and opportunities for the future. Small Business Economics, https://doi.org/10.1007/s11187-019-00149-6

Miles, M. B., \& Huberman, A. M. (1994). Qualitative data analysis: an expanded source book (2nd ed.). Thousand Oaks: SAGE.

Morel, B., \& Ramanujam, R. (1999). Through the looking glass of complexity: The dynamics of organizations as adaptive and evolving systems. Organization Science 10(3): 278-293.

Neergaard, H., \& Ulhøi, J.P. (2006). Government Agency and Trust in the Formation and Transformation of Interorganizational Entrepreneurial Networks. Entrepreneurship Theory and Practice, 30(4), 519539.

Okhuysen, G., \& Bonardi, J.-P. (2011). The challenges of building theory by combining lenses. Academy of Management Review (36), 6-11.

Parkhe, A. (1993). 'Messy' Research, methodological predispositions and theory development in international joint ventures. Academy of Management Review. 18 (2), 227-68.

Partanen, J., Chetty, S., \& Rajala, A. (2011). Innovation types and network relations. Entrepreneurship Theory and Practice 38(5), 1027-1055.

Patton, M.Q. (2015). Qualitative Research and Evaluation Methods. SAGE Publications, Saint Paul, MN.

Perry, J.T., G.N. Chandler, \& G. Markova (2012). Entrepreneurial effectuation: A review and suggestions for future research. Entrepreneurship Theory and Practice 36(4), 837-861.

Plowman, D.A., Solansky, S., Beck, T., Baker, L., Kulkarni, M., \& Travis, D.V. (2007). The role of leadership in emergent, self-organization. The Leadership Quarterly 18: 341-356.

Podolny, J.M. (2001). Networks as the pipes and prisms of the market. American Journal of Sociology, 107(1), 33-60.

Read, S., Dew, N., Sarasvathy, S.D., Song, M., \& Wiltbank, R. (2009). Marketing under uncertainty: The logic of effectuation approach. Journal of Marketing 73(3), 1-18.

Read, S., Sarasvathy S.D., Dew, N., \& Wiltbank, R. (2017). Effectual Entrepreneurship. $2^{\text {nd }}$ edition. New 
York, Routledge.

Read, S., Sarasvathy, S. D., Dew, N., \& Wiltbank, R. (2016). Response to Arend, Sarooghi, and Burkemper (2015): Cocreating effectual entrepreneurship research. Academy of Management Review 41(3), 528536.

Read, S., Song, M. \& Smith, W. (2009). A meta-analytic review of effectuation and venture performance. Journal of Business Venturing 24, 573-587.

Reuber, R., Fisher, E., \& Coviello, N. (2016). Deepening the dialogue: New directions for the evolution of effectuation theory. Academy of Management Review 41(3), 536-540.

Reymen, I. M. M. J., Andries, P., Berends, H., Mauer, R., Stephan, U., \& van Burg, E. (2015). Understanding dynamics of strategic decision making in venture creation: a process study of effectuation and causation. Strategic Entrepreneurship Journal 9(4), 351-379.

Ritter, T., Wilkinson, I.F., \& Johnston, W.J. (2004). Managing in complex business networks. Industrial Marketing Management, 33(3), 175-183.

Sarasvathy, S.D. \& Venkataraman, S. (2011). Entrepreneurship as method: Open questions for an entrepreneurial future. Entrepreneurship Theory and Practice 35(1), 113-135.

Sarasvathy, S.D. (2001). Causation and Effectuation: Toward a theoretical shift from economic inevitability to entrepreneurial contingency. Academy of Management Review 26 (2), 243-263.

Sarasvathy, S.D. (2008). Effectuation: Elements of Entrepreneurial Expertise. Edward Elgar, Cheltenham, UK.

Sarasvathy, S.D., \& Dew, N. (2003). Effectual Networks: A pre-commitment approach to bridging the gap between opportunism and trust. Proceedings of the Academy of Management Annual Meeting, Seattle, USA.

Sarasvathy, S.D., \& Dew, N. (2005). New Market Creation through Transformation. Journal of Evolutionary Economics 15(5), 533-565.

Sarasvathy, S.D., \& Dew, N. (2008). Effectuation and Over-Trust: Debating Goel and Karri. Entrepreneurship Theory and Practice 32(4), 727-737.

Schneider, M., \& Somers, M. (2006). Organizations as complex adaptive systems: Implications of complexity theory for leadership research. The Leadership Quarterly 17: 351-365.

Simon, H. (1969). The Science of the Artificial, 2nd ed. MIT Press, Boston, MA.

Simon, H. A. (1993). Altruism and Economics. American Economic Review 83, 156-161.

Simon, H.A., \& Chase, W.G. (1973). Skill in chess. American Scientist, 61, 393-403.

Slotte-Kock, S., \& Coviello, N. (2010). Entrepreneurship research on network processes: A review and ways forward. Entrepreneurship Theory and Practice 34(1), 31-57.

Smolka, K., Verheul, I., Burmeister-Lamp, K., \& Heygens, P. (2016). Get it together! Synergistic effects of causal and effectual decision-making logics on venture performance. Entrepreneurship Theory and Practice, DOI: 10.1111/etap.12266.

Staber, U. (1993). Friends, acquaintances, strangers: gender differences in the structure of entrepreneurial networks. Journal of Small Business and Entrepreneurship 11(1), 73-82.

Stake, R.E., 1995. The Art of Case Study Research. Thousand Oaks: SAGE Publications.

Sullivan, D., \& Ford, C. (2013). How entrepreneurs use networks to address changing resource requirements during early venture development. Entrepreneurship Theory and Practice 38(3), 551-574.

Svyantek, D. J., \& DeShon, R. P. (1993). Organizational attractors: A chaos theory explanation of why cultural change efforts often fail. Public Administration Quarterly, 339-355.

Thietart, R. A. \& Forgues, B. (1995). Chaos theory and organizations. Organization Science 6: 19-31.

Thrift, N. (1999). The place of complexity. Theory, Culture and Society 16 (3), 31-69.

Uzzi, B. (1997). Social Structure and Competition in Interfirm Networks: The Paradox of Embeddedness. Administrative Science Quarterly, 42(1), 36-67. 
Walby, S. (2007). Complexity theory, systems theory, and multiple intersecting social inequalities. Philosophy of the Social Sciences 37(4), 449-470.

Welter, C., \& Kim, S. (2018). Effectuation under risk and uncertainty: A simulation model. Journal of Business Venturing 33, 100-116.

Wiltbank, R., Read, S., Dew, N., \& Srasvathy, S.D. (2009). Prediction and control under uncertainty: Outcomes in angel investing. Journal of Business Venturing 24(2), 116-133.

Yin, R. K. (2014). Case study research: design and methods (5th ed.). Thousand Oaks: SAGE Publications, Inc. 


\section{Complex adaptive systems}

\begin{abstract}
Nature of the theory and underlying assumptions
\end{abstract}

Non-predictability

Connectivity

Self-organization

Co-evolution
Adaptability

Process-based complexity theory is applied to understand systems and their adaptive mechanisms of coping with uncertainty resulting from complexity; complexity is the inability to evaluate and predict the outcomes of actions because too many variables interact; focus on systems/structures; organizations are understood as a collections of strategies and structures

\section{Unit of analysis Organization/unit/system}

Sensitivity to initial A small change in the initial conditions can lead to conditions a completely different result

\section{Non-linearity}

No direct relationship between input and output; multiple interactions between the elements of a system

Based on learning from past experience and responding to internal and external changes pattern but not in path positive and negative feedback loops

\section{Effectual networks}

Process-based cognitive theory of effectuation is applied to understand decision-making and behavior under conditions of Knightian uncertainty, lack of goal specificity and information isotropy

Individual entrepreneur

The networking process outcome is sensitive to entrepreneurial means: What I am, What I know; Whom I know

Reliance on the immediate reality, resources at hand and flexible nature of interactive commitments allows iterative feedback loops and for numerous potentially co-created effects

Based on cooperative and interactive control of the future rather than predicting it; flexible and adaptive nature of effectual asks and commitments; reacting to contingencies and exploiting them requires a "prepared mind" and adaptive behavior

Effectual logic is based not on prediction but on control of an unpredictable future; non-goal driven reasoning

Change cannot be planned because some behav are impossible to predict; CASs are predictable in

Elements of a system are connected through
Entrepreneurs receive positive and negative feedback on their ventures from other stakeholders; through series of interactive commitments, they establish connectivity between stakeholders and co-create their ventures with them

Interactive commitments and self-selection become patterns of behavior; a new venture or an entrepreneurial idea serve as an attractor, around which effectual networks get self-organized

Effectual asks grow into commitments, which allows for co-creation and co-development and any stakeholder can change the process; parts of effectual networks co-evolve through the mechanism of interrelated commitments 
Table 2. The data collection phase of the study

\begin{tabular}{|c|c|c|}
\hline Startup and its core business & Respondents & Time and duration of the interviews \\
\hline $\begin{array}{l}\text { SU1. Web application for connecting } \\
\text { people. Legally registered: December } \\
2016\end{array}$ & $\begin{array}{l}\text { F1: 34-year-old male, background in environmental } \\
\text { engineering; } \\
\text { F2: } 32 \text {-year-old male, background in marketing and biology }\end{array}$ & $\begin{array}{l}\text { F1: } 3.12 .2016(47 \mathrm{~min} .) \\
\text { F2: } 3.12 .2016(50 \mathrm{~min} .)\end{array}$ \\
\hline $\begin{array}{l}\text { SU2. Web application for reading codes } \\
\text { on documents, letters and mailers. } \\
\text { Legally registered: October } 2016\end{array}$ & $\begin{array}{l}\text { F1: } 55 \text {-year-old male, background in printing technologies; } \\
\text { F2: c. } 55 \text {-year-old male, background in postage equipment; } \\
\text { F3: c. } 60 \text {-year-old male, background in sales }\end{array}$ & $\begin{array}{l}\text { F1: 4.12.2016 (87 } \mathrm{min} .) \\
\text { F2: 4.12.2016 (61 } \mathrm{min} .) \\
\text { F3: } 4.12 .2016(72 \mathrm{~min} .)\end{array}$ \\
\hline $\begin{array}{l}\text { SU3. Web application for restaurants. } \\
\text { Legally registered: November } 2016\end{array}$ & $\begin{array}{l}\text { F1: } 25 \text {-year-old female, background in branding; } \\
\text { F2: } 25 \text {-year-old male, background in architecture and } \\
\text { programming }\end{array}$ & $\begin{array}{l}\text { F1: } 5.12 .2016(45 \mathrm{~min} .) \\
\text { F2: } 5.12 .2016(65 \mathrm{~min} .)\end{array}$ \\
\hline $\begin{array}{l}\text { SU4. Web application for creating video } \\
\text { content. Legally registered: May } 2016\end{array}$ & $\begin{array}{l}\text { F1: } 35 \text {-year-old male; background in marketing, multiple } \\
\text { entrepreneur; } \\
\text { F2: } 36 \text {-year-old male, background in video content and } \\
\text { advertising }\end{array}$ & $\begin{array}{l}\text { F1: } 7.12 .2016(56 \mathrm{~min} .) \\
\text { F2: } 20.1 .2017(74 \mathrm{~min} .)\end{array}$ \\
\hline $\begin{array}{l}\text { SU5. Spray printing and web application } \\
\text { for spray printing. } \\
\text { Legally registered: January } 2016\end{array}$ & $\begin{array}{l}\text { F1: 34-year-old male, multiple entrepreneur; } \\
\text { F2: } 37 \text {-year-old male, background in information } \\
\text { technologies; } \\
\text { F3: } 32 \text {-year-old female, background in sales and printing }\end{array}$ & $\begin{array}{l}\text { F1: } 12.12 .2016(49 \mathrm{~min} .) \\
\text { F2: } 12.12 .2016(47 \mathrm{~min} .) \\
\text { F3: } 5.1 .2017 \text { (62 } \mathrm{min} .)\end{array}$ \\
\hline $\begin{array}{l}\text { SU6. Web application for eco food } \\
\text { delivery. Legally registered: September } \\
2014\end{array}$ & $\begin{array}{l}\text { F (sole founder): } 28 \text {-year-old female, studies business, } \\
\text { worked as a flight attendant }\end{array}$ & $\mathrm{F}: 15.12 .2016$ (45 min.) \\
\hline $\begin{array}{l}\text { SU7. Web application for creating digital } \\
\text { publications. Legally registered: January } \\
2016\end{array}$ & $\begin{array}{l}\text { F1: 27-year-old male, background in software engineering; } \\
\text { F2: } 32 \text {-year-old male, background in programming; } \\
\text { F3: c. } 30 \text {-year-old male, background in software } \\
\text { engineering }\end{array}$ & $\begin{array}{l}\text { F1: } 21.12 .2016(45 \mathrm{~min} .) \\
\text { F2: } 22.12 .2016(70 \mathrm{~min} .) \\
\text { F3: } 22.12 .2016(85 \mathrm{~min} .)\end{array}$ \\
\hline $\begin{array}{l}\text { SU8. Web application for finding a pet- } \\
\text { sitter. Legally registered: April } 2015\end{array}$ & $\begin{array}{l}\text { F1: 32-year-old female, background in sales and marketing; } \\
\text { F2: 39-year-old male, background in programming }\end{array}$ & $\begin{array}{l}\text { F1: } 10.1 .2017(80 \mathrm{~min} .) \\
\text { F2: } 9.1 .2017(73 \mathrm{~min} .)\end{array}$ \\
\hline $\begin{array}{l}\text { SU9. Web application for creating } \\
\text { customer profiles. Legally registered: } \\
\text { November } 2015\end{array}$ & $\begin{array}{l}\text { F1: c. } 55 \text {-year-old male, multiple entrepreneur; } \\
\text { F2: c. } 50 \text {-year-old male, background in marketing; } \\
\text { F3: c. } 50 \text {-year-old male, multiple entrepreneur }\end{array}$ & $\begin{array}{l}\text { F1: 10.1.2017 (88 min.) } \\
\text { F2: 20.1.2017 (71 min.) } \\
\text { F3: (27.1.2017 (77 min.) }\end{array}$ \\
\hline $\begin{array}{l}\text { SU10. Web application for customizing } \\
\text { shoes. Legally registered: January } 2016\end{array}$ & $\begin{array}{l}\text { F1: 28-year-old male, multiple entrepreneur; } \\
\text { F2: } 29 \text {-year-old male, background in sales }\end{array}$ & $\begin{array}{l}\text { F1: } 16.1 .2017(90 \mathrm{~min} .) \\
\text { F2: } 17.1 .2017(68 \mathrm{~min} .)\end{array}$ \\
\hline
\end{tabular}

\section{SU- startup: F - founder}


First-order concepts

\begin{tabular}{|c|c|}
\hline \multirow[t]{6}{*}{$\begin{array}{l}\text { Pre- } \\
\text { network } \\
\text { phase }\end{array}$} & $\begin{array}{l}\text { - What I am } \\
\text { - What I know } \\
\text { - Whom I know }\end{array}$ \\
\hline & - Whom I know but don't need at the moment \\
\hline & - Whom I know but can't use at the moment \\
\hline & - Whom I know but don't perceive as means \\
\hline & - Whom I don't know but would like to know \\
\hline & $\begin{array}{l}\text { - Urge to use means } \\
\text { - Desire to experiment with means }\end{array}$ \\
\hline \multirow{4}{*}{$\begin{array}{l}\text { Forma- } \\
\text { tion }\end{array}$} & - Asks crafted for getting feedback \\
\hline & $\begin{array}{l}\text { - Iterative communication } \\
\text { - Loops of evaluation }\end{array}$ \\
\hline & $\begin{array}{l}\text { - Offers to potential partners } \\
\text { - Affordable loss }\end{array}$ \\
\hline & $\begin{array}{l}\text { - Partners co-create an entrepreneurial idea } \\
\text { - Partners attracted by an idea }\end{array}$ \\
\hline \multirow{4}{*}{$\begin{array}{l}\text { Effectual } \\
\text { network } \\
\text { phase }\end{array}$} & $\begin{array}{l}\text { - Stakes something valuable to relationships } \\
\text { - Commitments to give }\end{array}$ \\
\hline & - Established connections \\
\hline & - New connections \\
\hline & $\begin{array}{l}\text { - Self-organized regularities of interactions } \\
\text { - Working norms and standards }\end{array}$ \\
\hline
\end{tabular}

\begin{tabular}{|l|l|}
\hline \multirow{2}{*}{\begin{tabular}{l} 
Pre- $\begin{array}{l}\text { network } \\
\text { phase }\end{array}$ \\
\cline { 2 - 2 }
\end{tabular}} & $\begin{array}{l}\text { - Scanning through relations } \\
\text { - Realizing what I am }\end{array}$ \\
\cline { 2 - 3 } $\begin{array}{l}\text { Forma- } \\
\text { tion }\end{array}$ & $\begin{array}{l}\text { - Unrestricted and open interactions } \\
\text { - Idea validation through feedback from various stakeholders }\end{array}$ \\
\cline { 2 - 3 } & $\begin{array}{l}\text { - Realizing relevant contacts } \\
\text { - Bundling relations }\end{array}$ \\
\cline { 2 - 3 } & $\begin{array}{l}\text { - Growing number of interactions } \\
\text { - Achieving new quality of network }\end{array}$ \\
\hline \multirow{2}{*}{$\begin{array}{l}\text { Effectual } \\
\text { network } \\
\text { phase }\end{array}$} & $\begin{array}{l}\text { - Committing as assuring partnership } \\
\text { - Self-selection into a network }\end{array}$ \\
\cline { 2 - 3 } & $\begin{array}{l}\text { - Staying in touch with partners } \\
\text { - Demonstrating empathy and interest in relations }\end{array}$ \\
\cline { 2 - 3 } & $\begin{array}{l}\text { - Evaluating new relations } \\
\text { - Achieving the fit with existing connections }\end{array}$ \\
\hline
\end{tabular}

Aggregate dimensions

$\left.\begin{array}{|c|}\hline \text { Actual means } \\ \hline \text { Dormant means } \\ \hline \text { Non-functional means } \\ \hline \text { Latent means } \\ \hline \text { Unavailable means } \\ \hline \begin{array}{c}\text { Willingness to proceed } \\ \text { further with the set of } \\ \text { means }\end{array} \\ \hline \text { Effectual asks } \\ \hline \begin{array}{c}\text { Feedback loops } \\ \text { Stakes that entrepreneurs } \\ \text { can afford to lose }\end{array} \\ \hline \begin{array}{c}\text { An entrepreneurial idea as } \\ \text { an attractor }\end{array} \\ \hline \begin{array}{c}\text { Actual commitments } \\ \text { Self-organized patterns of } \\ \text { interactions }\end{array} \\ \hline \text { Established connections } \\ \hline \text { New connections } \\ \hline\end{array}\right\}$

\begin{tabular}{|c|}
\hline Scanning for means \\
\hline Realizing means \\
\hline $\begin{array}{c}\text { Interacting with all and } \\
\text { any stakeholders }\end{array}$ \\
\hline $\begin{array}{c}\text { Establishing connectivity } \\
\text { among interactions }\end{array}$ \\
\hline $\begin{array}{c}\text { Achieving a critical mass of } \\
\text { interactions }\end{array}$ \\
\hline $\begin{array}{c}\text { Self-selection } \\
\text { Maintaining existing } \\
\text { relations }\end{array}$ \\
\hline $\begin{array}{c}\text { Adjusting the fit between } \\
\text { existing and new } \\
\text { connections }\end{array}$ \\
factors \\
Dynamic \\
fons
\end{tabular}


Table 4. Inference from raw data to concepts, themes and aggregate dimensions - 1

\section{Raw data excerpts}

F1, SU 5: "Before starting this company, I already had an extensive network of relations from my previous experience as an entrepreneur and also from my past studies and work. This was a good luggage to carry! And this was as a pre-condition for the new start... in a way it is path dependent,but I tried to use it differently because I learnt my lesson from the previous failure."

F, SU6: "I use a lot the contacts I have in my immediate surrounding... friends, former colleagues... This is what I have".

F1, SU5: "Connections is also a part of this luggage [what I have] Some relations are there but you don't need them for the moment, but you know they are useful and might help one day. Some relations just can't be used because of... there can be many situations, issues of reputation or if you use them it will harm other partners. It also can be that I just don't know my network well enough and some of my relations can be of a very big help, but I just don't realize it..."
Codes

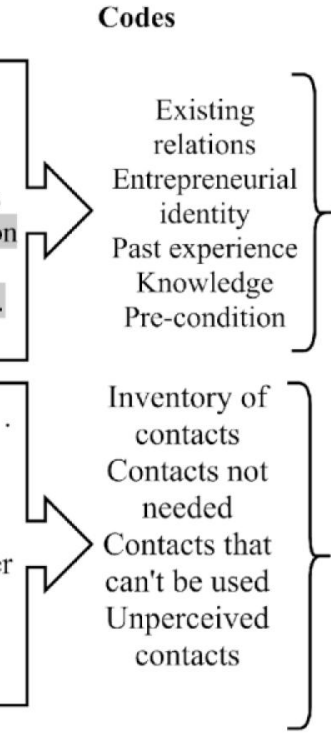

\section{First-order Second-order concepts \\ themes}

$\left.\begin{array}{c}\text { What I am } \\ \text { What I know } \\ \text { Whom I know }\end{array}\right\}$ Actual means

$\left.\begin{array}{c}\text { Whom I know but } \\ \text { don't need at the } \\ \text { moment }\end{array}\right\} \begin{gathered}\text { Dormant } \\ \text { means }\end{gathered}$

Whom I know but 7 Non-

can't use at the $\}$ functional

moment

$\int$ means

Whom I know

but don't

perceive as

F3, SU5: "Knowing what you are and what you have also show these gaps. it is very natural... Knowing whom I know, helps me to see whom I don't know and would like to know... and then I start to see what to do. Do I have this kind of person in my surrounding or I need to find him". means

Structural

factors
What I don't

have

Gap

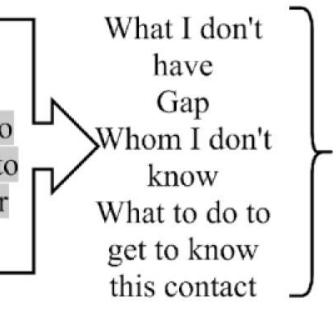

\section{$\left.\begin{array}{c}\text { Whom I don't } \\ \text { know but } \\ \text { would like to }\end{array}\right\} \begin{gathered}\text { Unavailable } \\ \text { means }\end{gathered}$}

Aggregate dimensions What makes the difference is the urge, the desire to start doing something with them. I know people with very big potential, but they just don't develop it. I am not a superman, I just really wanted to "play" with what I had, I started very small..."

F2, SU9: "I don't know how to call it... but it is similar to kids: give two kids two identical sets of objects, one may not even touch it, the other one will experiment, construct something. It is about passivity and activity, some start, some don't..."
F1, SU1: "I think everybody has some resources to start a business.

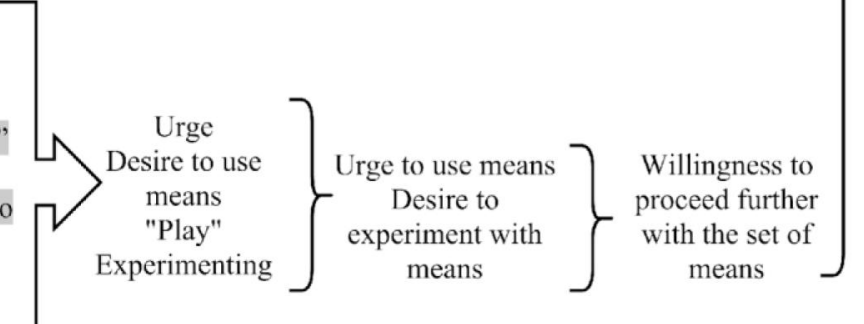

F2, SU8: "When I decided to start this business, I was like 'Ok, who can help me?'; it was like a scanning process... Or perhaps it was also the other way round... I started because I had so many assets,

F2, SU8: "Wh
can help me?';
also the other
my network".

F1, SU10: "It was a long process of learning about myself, it wasn't painful, it was interesting and natural, and I am still learning. I tried to understand what I really want to do in life and what I have for it. I knew that I want to have my own business, so it was part of me from the very beginning",

F2, SU3: "I don't think it is enough to have knowledge and connections We all have some of it... I think what what makes an entrepreneur is his constant reflection and efforts to understand how he can use them to make business"

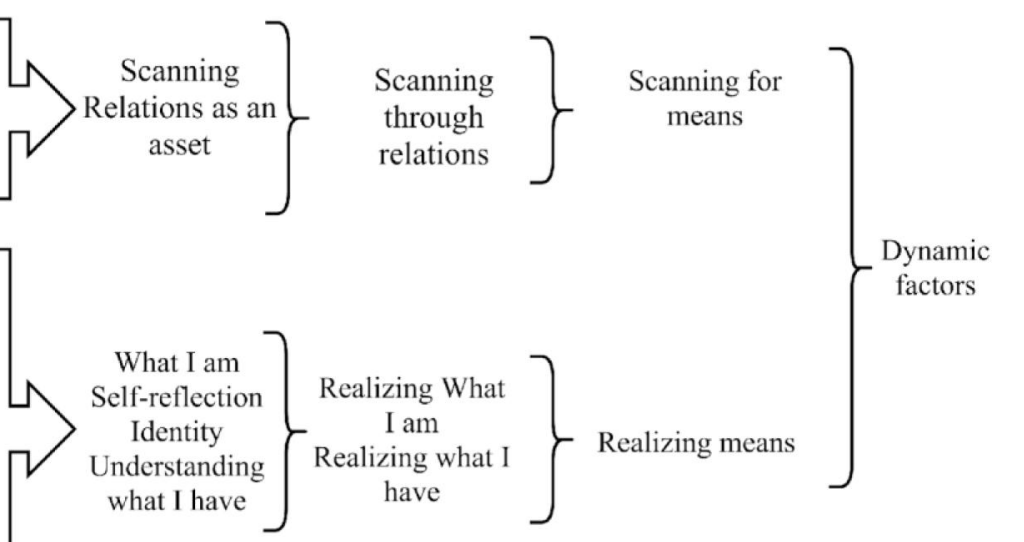


Table 5. Inference from raw data to concepts, themes and aggregate dimensions - 2

\begin{tabular}{|c|c|c|c|c|}
\hline Raw data excerpts & Codes & $\begin{array}{l}\text { First-order } \\
\text { concepts }\end{array}$ & $\begin{array}{l}\text { Second-order } \\
\text { themes }\end{array}$ & $\begin{array}{l}\text { Aggregate } \\
\text { dimensions }\end{array}$ \\
\hline $\begin{array}{l}\text { F2, SU9: "When I got my idea in mind, I was asking and asking. I tried to get } \\
\text { as much feedback as possible... from my wide, friends... anybody". }\end{array}$ & $\begin{array}{l}\text { y of asks } \\
\text { dback }\end{array}$ & $\begin{array}{l}\text { Asks crafted for } \\
\text { getting feedback }\end{array}$ & $\begin{array}{l}\text { Effectual } \\
\text { asks }\end{array}$ & \\
\hline $\begin{array}{l}\text { F2, SU2: "Connections are very important for iterative validation of your } \\
\text { initial ideas. It is like looping... like iterative change and constant } \\
\text { improvement... From one hand a lot of new connections are difficult to track, } \\
\text { but on the other hand things get more certain". }\end{array}$ & $\begin{array}{l}\text { Iterative change } \\
\quad \text { Looping } \\
\text { Idea changes } \\
\text { and improves }\end{array}$ & $\begin{array}{l}\text { Iterative } \\
\text { communication } \\
\text { Loops of } \\
\text { evaluation }\end{array}$ & $\begin{array}{c}\text { Feedback } \\
\text { loops }\end{array}$ & \\
\hline $\begin{array}{l}\text { F2, SU3: "Networking is an activity that costs nothing because it is natural, } \\
\text { you only need time and courage. But once you have it, you just go and stay } \\
\text { humble and open. Anyone can afford doing it! You don't lose anything but } \\
\text { your time, maybe... and even this time is not a loss, you gain experience } \\
\text { anyway!" } \\
\text { F3, SU9: "Usually, I am very open. When we have the first meeting [with } \\
\text { potential partner], I say 'I have an idea, some budget to use, will you join me?' } \\
\text { Then this person thinks 'Hmm... I also have some thoughts to improve this } \\
\text { idea, and maybe I can contribute with my budget' Them we see what we can } \\
\text { _do together, no guarantee it would work, but we try!" }\end{array}$ & $\begin{array}{c}\text { No cost } \\
\text { Affording } \\
\text { No loss } \\
\text { Time as a loss } \\
\text { Gaining experience } \\
\text { No guaranties } \\
\text { Staking own idea } \\
\text { and budget } \\
\text { Openness }\end{array}$ & $\begin{array}{l}\text { Offers to potential } \\
\text { partners } \\
\text { Affordable loss }\end{array}$ & $\begin{array}{l}\text { Stakes than an } \\
\text { entrepreneur can } \\
\text { afford to lose }\end{array}$ & $\begin{array}{l}\text { Structural } \\
\text { factors }\end{array}$ \\
\hline $\begin{array}{l}\text { F1, SU1: "I think what kept them [partners] around us was our strong idea that } \\
\text { we believed in and made them believe too...". } \\
\text { F1, SU7: "When your idea gets into the right shape, it starts to attract people... } \\
\text { And when you have all these necessary people, it shows that this idea has a } \\
\text { right to exist...". } \\
\text { F1, SU5: "In the beginning, you as a person and your idea that sells are the } \\
\text { most important things. It [the idea] either attracts people or not. And it is } \\
\text { amazing how other people can believe in this idea even it is not ready! They }\end{array}$ & $\begin{array}{c}\text { Idea } \\
\text { Partners as } \\
\text { part of an idea } \\
\text { Idea attracting } \\
\text { partners }\end{array}$ & $\begin{array}{l}\text { Partners co-create } \\
\text { an entrepreneurial } \\
\text { idea } \\
\text { Partners attracted } \\
\text { by an idea }\end{array}$ & $\begin{array}{l}\text { An } \\
\text { entrepreneurial } \\
\text { idea as an } \\
\text { attractor }\end{array}$ & \\
\hline
\end{tabular}
just want to be a part of it if (and when) it is out".

F2, SU2: "We are very active in networking. But we don't carefully select people. We are just open to any input because it can give an interesting direction to our idea. It is very self-organized. We don't really coordinate it...". F1, SU1: "It was a process of active networking, which shaped both my idea and gave a new form of my existing network, my network started to expand. I was telling about my idea to everybody. I was constantly rethinking and reevaluating my idea. It got crystallized through this feedback from others".
Networking No careful selection of people

Openness to any input

Self-organized

No coordination

Network growth

Feedback

Talking to everybody

Validating ideas

$$
\left.\begin{array}{c}
\text { Unrestricted } \\
\text { and open } \\
\text { interactions } \\
\text { Idea validation } \\
\text { through } \\
\text { feedback from } \\
\text { various } \\
\text { stakeholders }
\end{array}\right\} \begin{gathered}
\text { Interacting } \\
\text { with all and } \\
\text { any } \\
\text { interested } \\
\text { stakeholders }
\end{gathered}
$$

F2, SU5: "When we were just shaping our idea (it was before the legal startup), we were involved into so many different conversations, and meetings... It was a huge puzzle! But with the time, we could see which contacts were more relevant, we started to connect our different contacts together, introduce people to each other, pulling the threads into one bundle, so to say...".

$\checkmark$

Relevant contacts Connecting contacts Relationship bundle

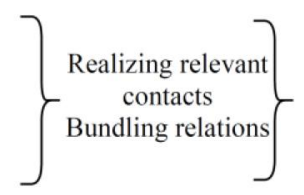

Establishing connectivity among interactions
Dynamic factors
F1, SU6: "It is not enough just to network and talk to people from time to time. When your business is at this pre-foundation stage, you need to do it a lot. It is like training for sports. You practice and practice and practice, nothing happens, you think you don't progress... but then, tadaam! You finally can make some element or lift this much weight! Same in start-ups... this pot boils and boils, and then, click! You feel this idea is ready, you have enough good people".

F3, SU5: "When you network a lot, at some point quantity grows into quality. You feel that through all these people you know your business better and your network gets more solid".
Not enough just to talk to people

Networking is like sport

Network as a

boiling pot

Critical mass

Quantity changes to quality

More solid network
Growing number of interactions

Achieving new quality of network
Achieving a critical mass of interactions 
Table 6. Inference from raw data to concepts, themes and aggregate dimensions - 3

Raw data excerpts

F2, SU3: "I think it is not enough just to ask people for advice on how to improve your idea. You may end up just talking... It may work for a while... but the next step is to start actually doing something with some of them [these people]. Get together a team and just start!"

F1, SU8: "Any partnership is about commitment and really giving something for this relations. Otherwise, it is just people whom you know. I know many but I am not a partner with many..."

F2, SU10: "Networks are alive...They are in a way settled, contain existing relations, something stable. But they also change because new relations appear; so they are never final"

\section{F3, SU5: "When network gets into some visible shape, then it becomes more clear who does what, how regularly and on what matters we need to meet, relations become workable". \\ SU1, F5: " It is all self-organized, no one makes it on purpose, it is natural that after some time we with our partners develop some patterns, norms of interactions and follow working standards"}

\section{F2, SU 2: "I don't think it's me [an entrepreneur]} who selects them [partners] into a network. That would be too naive to think that its only me who decides this. It is selfoccurring... When they [partners] want to do something with us, they somehow already become a part of our network... at least because they invest their time and hopefully money to us... When we commit, we are partners"
F1, SU9: "Yes, business contacts need maintenance; but it is not hard. It is very natural. When you meet people on a regular basis for business you don't even think like 'Ok, now I am working on maintaining these relations'. You ask how they are, call them from time to time, have some deals with them. It is about empathy and showing that you're interested"

F2, SU1: "Networking is an interesting thing... On one hand,you always need to network and be active. On another hand, at some point you start having workable relations, which means that you don't need to search for new ones that much... Or the new ones really need to add value to the existing relations, so you evaluate them in relation to what you already have. This usually happens when your firm is legally registered, and it is not only your idea anymore but it turns into a concrete business".

F2, SU7: "I can give you an example. We had one client. And then another company also wanted our product, but they were competitors with our first client. So, we really had to think twice how to do it not to spoil relations with that client... I think when you already have a network of some sort you start thinking whether other added relations would fit or how they will change them and if they join this fit has to be achieved".
Codes

Asking is not enough

Actually doing something

together

Partnership is

commitment

Giving

Stakes

Existing

relations

Stable

Settled

New relations

not final

Regularities

Norms of

interactions

Working

standards

Self-

organization

$$
\}
$$

First-order
concepts

Second-order

Aggregate

themes

dimensions

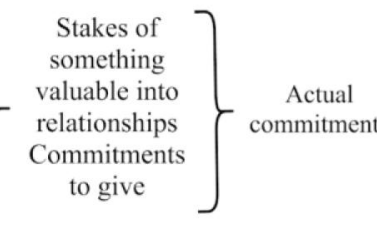

Structural

factors

Self-occurring

Entrepreneur

does not select

partners into a

network

Committing

time and

money

Partnership

means

commitments

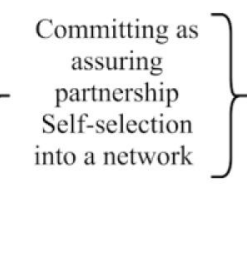

Established

Established connections

New connections $\$

connections

New connections

Self-organized regularities of

interactions

Working norms and standards

Selforganized patterns of interactions
Selfselection

$\left.\begin{array}{c}\text { Maintenance } \\ \text { Natural } \\ \text { Existing } \\ \text { relations } \\ \text { Staying in touch } \\ \text { Empathy } \\ \text { Showing } \\ \text { interest }\end{array}\right\}$

interest

$$
\left.\begin{array}{c}
\text { Staying in } \\
\text { touch with } \\
\text { partners } \\
\text { Demonstrating } \\
\text { empathy and } \\
\text { interest in } \\
\text { relations }
\end{array}\right\}
$$

\author{
$\triangle$ \\ New \\ relations \\ adding value \\ Evaluating \\ new relations \\ vis-a-vis \\ existing ones \\ Acheiving \\ the fit
}

Evaluating new relations

Achieving the fit with existing connections
Adjusting the fit between existing and new connections
Dynamic factors 
Table 7. Entrepreneur-related dynamic and structural factors of effectual network emergence

\begin{tabular}{|c|c|c|}
\hline & Structural factors & Dynamic factors \\
\hline Pre-network phase & $\begin{array}{l}\text { - Available means: } \\
\circ \quad \text { Actual means } \\
\circ \text { Dormant means } \\
\circ \text { Non-functional means } \\
\circ \quad \text { Latent means } \\
\text { - Unavailable means } \\
\text { - Willingness to proceed further with the set of } \\
\text { means }\end{array}$ & $\begin{array}{l}\text { - Scanning for means } \\
\text { - Realizing means }\end{array}$ \\
\hline Formation & $\begin{array}{l}\text { - Effectual asks } \\
\text { - Feedback loops } \\
\text { - Stakes that entrepreneurs can afford to lose } \\
\text { - An entrepreneurial idea as an attractor }\end{array}$ & $\begin{array}{l}\text { - Interacting with all and any stakeholders } \\
\text { - Establishing connectivity among interactions } \\
\text { - Achieving a critical mass of interactions }\end{array}$ \\
\hline $\begin{array}{l}\text { Effectual network } \\
\text { phase }\end{array}$ & $\begin{array}{l}\text { - Actual commitments } \\
\text { - Established connections } \\
\text { - New connections } \\
\text { - Self-organized patterns of interactions }\end{array}$ & $\begin{array}{l}\text { - Self-selection } \\
\text { - Maintaining established relations } \\
\text { - Adjusting the fit between established and } \\
\text { new connections }\end{array}$ \\
\hline
\end{tabular}




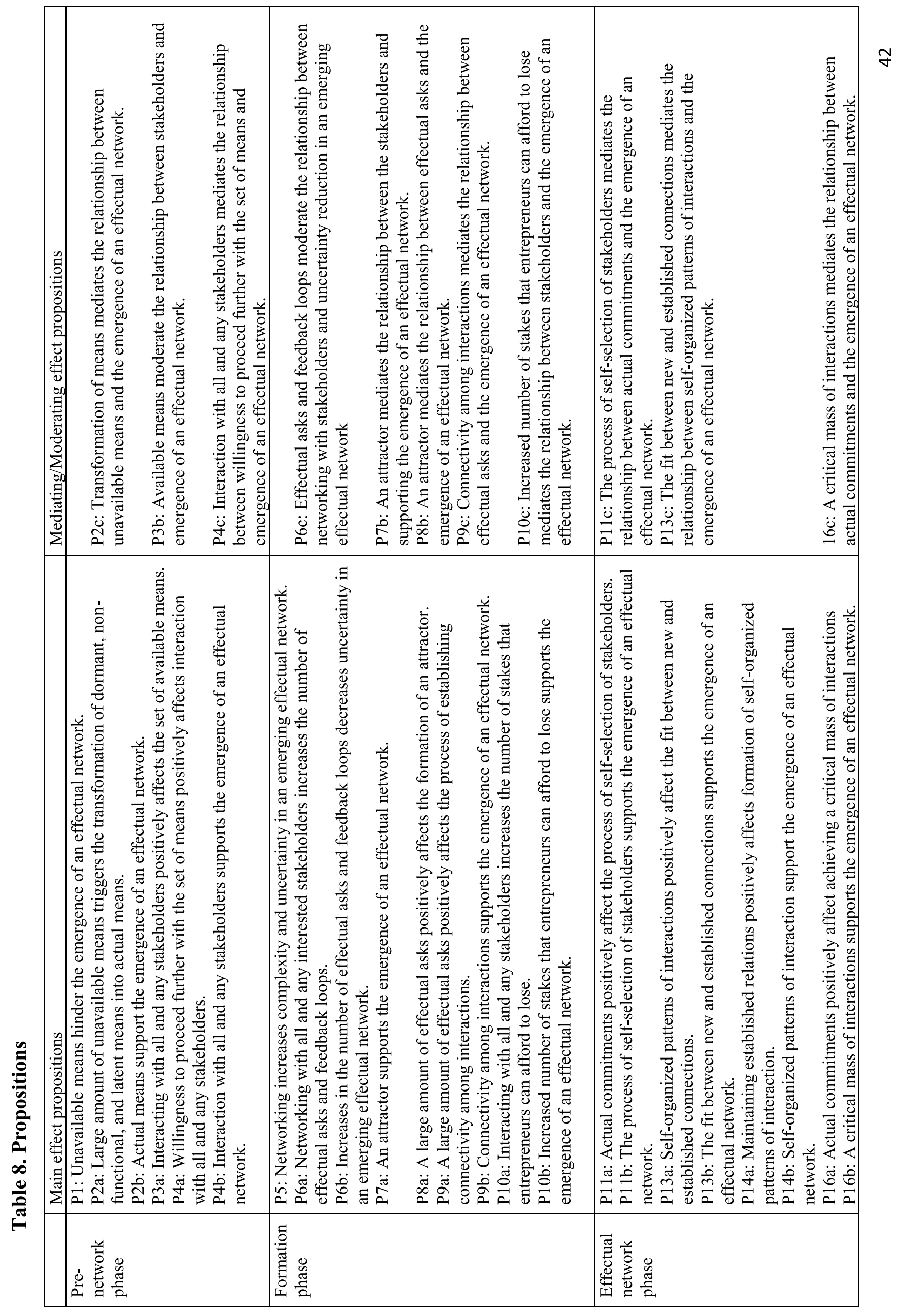




\section{Figure 1. Process-system model of effectual networks as CASs}

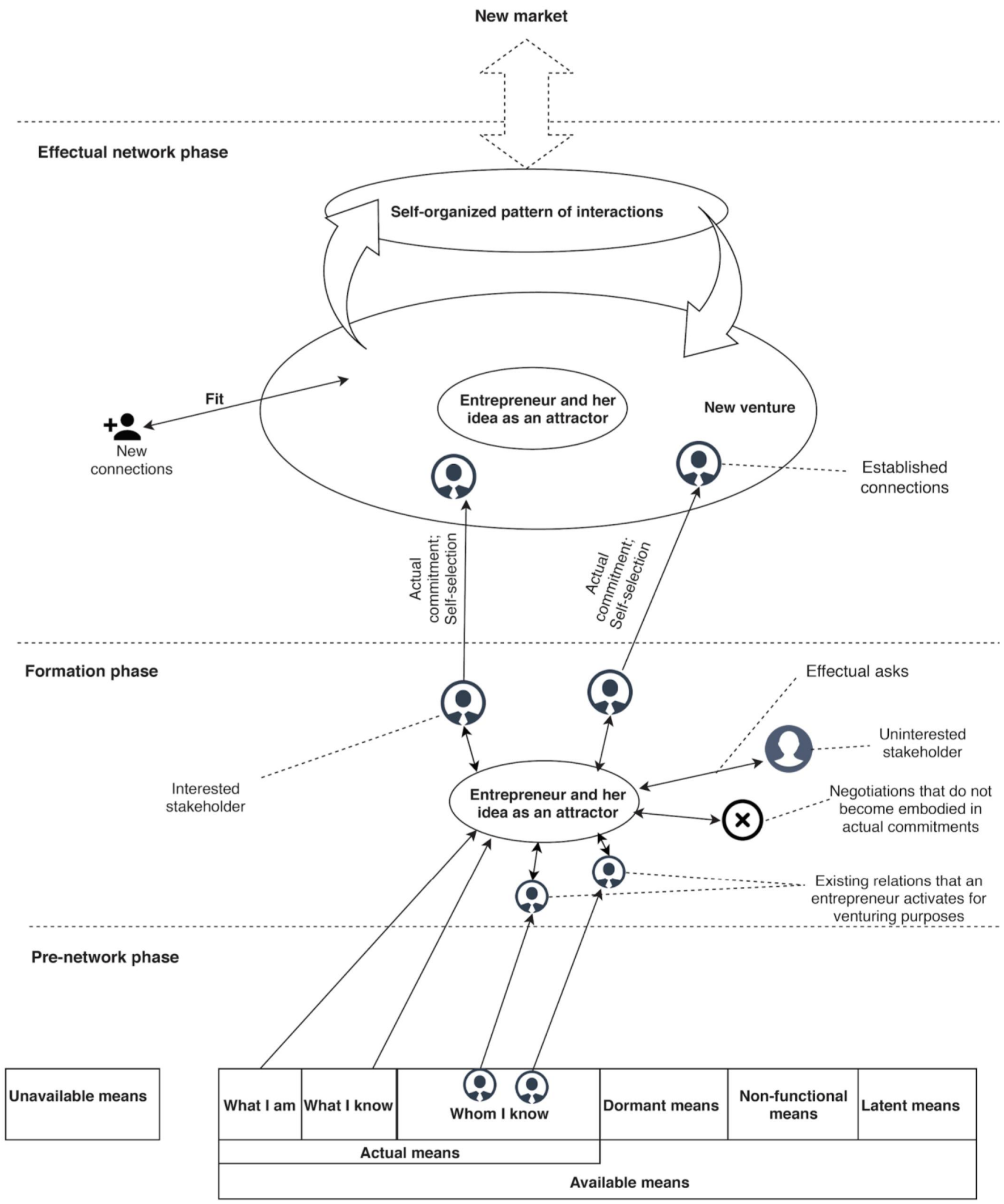

